\title{
USING FORCE ON LAND TO SUPPRESS PIRACY AT SEA: THE LEGAL LANDSCAPE OF A LARGELY UNTAPPED STRATEGY
}

\author{
STEVEN R. OBERT*
}

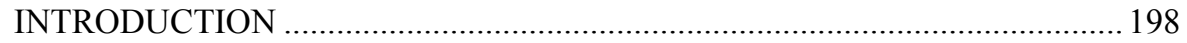

I. JUSTIFICATIONS FOR THE USE OF FORCE IN SOMALIA ........................ 201

A. U.N. Security Council action under Chapter VII ................................. 204

1. Resolution 1851: Authorization and Restrictions of Operative

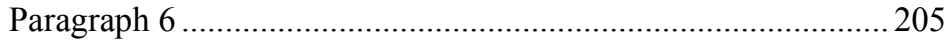

2. Other indications that Resolution 1851 authorizes military

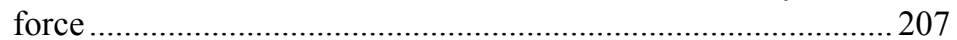

B. Consent of the sovereign ................................................................ 210

C. Self-defense ..................................................................................... 211

II. LAW APPLICABLE TO THE USE OF FORCE IN SOMALIA ....................2 213

A. If a NIAC were to exist, IHL would clearly apply ............................214

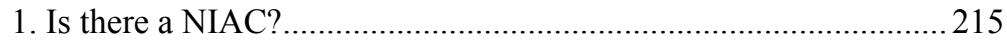

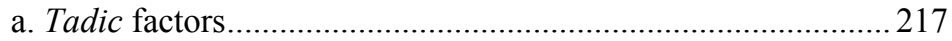

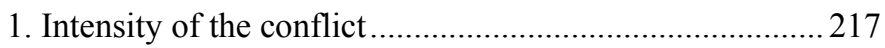

2. Organization of the parties............................................. 218

3. Challenges to applying the Tadic framework ..................2 219

b. Problems presented by the pirate-fighter case to the

definition of NIAC ............................................................ 222

1. Law enforcement overlap ............................................. 223

2. State practice and the challenge of recognition .............. 223

2. If there is a NIAC, how would IHL be applied? ..........................226

a. Destruction of pirates' materiel............................................. 226

Copyright (C) 2014 by Steven R. Obert

*Lieutenant Commander, Judge Advocate General's Corps, U.S. Navy. LL.M., James Kent Scholar, Columbia Law School (2013); J.D. (with honors), The George Washington University Law School (2007); B.A. (with honors in Economics), Northwestern University (1999). I currently serve as the staff judge advocate to Commander, Carrier Strike Group Twelve, embarked in USS Theodore Roosevelt (CVN 71). I recently served as international law attorney on the staff of U.S. Naval Forces Europe/Africa in Naples, Italy, and earlier was deployed twice as a qualified nuclear engineer officer in the fast-attack submarine USS Hampton (SSN 767). The views expressed in this article are entirely my own and do not necessarily reflect the views of the United States Government, the Department of Defense, the United States Navy, or any other governmental or nongovernmental entity. All information obtained for this Article was gathered through open sources or unclassified interviews and briefings. I would like to thank Joseph Boveri, Lori Damrosch, Gordon Modarai, Mark Nevitt, Gabor Rona, and Matthew Waxman for their helpful comments on previous drafts. 
b. Possible targeting of pirate fighters 228

B. If the conflict falls short of a NIAC, could IHL still apply?..............230

1. Applicability of IHL to "gray zone" conflicts ............................2230

2. Association with the existing NIAC in Somalia........................... 232

C. If IHL were not applied, what law would apply?

\section{INTRODUCTION}

On May 14, 2012, a combat helicopter operated by European Union Naval Forces (EUNAVFOR) struck a pirate base ashore in Somalia. ${ }^{1}$ The raid destroyed several fiberglass skiffs on the beach in Haradheere, a town on the coast of central Somalia. ${ }^{2}$ The attack represented a new tactic used in the protracted and evolving international effort to fight maritime piracy off the coast of Somalia. It was the first time that force ashore, first authorized by the United Nations Security Council in 2008, had been publicly acknowledged. ${ }^{3}$

Though recently receding, piracy off the coast of Somalia has had a destabilizing effect on maritime commerce since at least 2008. ${ }^{4}$ The problem has not suffered from lack of attention. Navies from across the globe patrol the seas off of Somalia, many multinational conferences have addressed the issue, and dozens of articles have analyzed and suggested solutions to the problem. ${ }^{5}$ Many observers have explained the recent drop by pointing to the increased use of private armed security teams on commercial vessels that transit pirate-infested waters. ${ }^{6}$ While that may be the case, this Article examines the legal framework for a strategy that has not been attempted on any great scale - the use of military force ashore in Somalia to disrupt and deter piracy off its coast.

This analysis is important for at least two reasons. First, piracy might only be receding temporarily. Little has been done on land in Somalia to

1. Jeffrey Gettleman, Toughening its Stand, European Union Sends Forces to Strike Somali Pirate Base, N.Y. TIMES, May 15, 2012, http:/www.nytimes.com/2012/05/16/world/africa/europeanforces-strike-pirate-base-in-somalia.html.

2. Id.

3. Id.

4. Int'1 Mar. Org., Reports on Acts of Piracy and Armed Robbery Against Ships, Annual Report2009 2, IMO Doc. MSC.4/Circ. 152 (Mar. 29, 2010) [hereinafter IMO Piracy Report].

5. See U.N. Secretary-General, Report of the Secretary-General Pursuant to Security Council Resolution 1950, ๆ 16-50, U.N. Doc. S/2011/662 (Oct. 25, 2010) [hereinafter Res. 1950 Report].

6. See Security Keeping Gulf of Aden Pirates at Bay, Ocean Protection Services (June 29, 2012), http://www.oceanprotectionservices.com/articles/?p=1865 (“...[the] Minister of Shipping for the Department of Transport in the UK [.. . said the adoption of more self-defensive measures by private shipping companies to fend off pirate attacks is certainly helping to stem the onslaught of marauding pirates"). 
disrupt the pirates' core infrastructure and capabilities. Indeed, as recently as August 2013, fifty-seven hostages and four vessels were still being held for ransom, though hostages continue to be released and the number has continued to drop. ${ }^{7}$ Second, piracy is not a new phenomenon. A close look at the legal framework for the use of force ashore that developed in this recent flare-up could yield important lessons for dealing more effectively with future problems.

Throughout this crisis, military and maritime security experts identified action ashore as most likely to disrupt piracy off the coast of Somalia. ${ }^{8}$ The U.N. Security Council, which has addressed the issue many times, first authorized in 2008 "all necessary measures . . . in Somalia" to suppress piracy at sea, and has subsequently renewed its authorization on an annual basis. ${ }^{9}$ Even so, the EUNAVFOR's May 2012 strike in Haradheere was the first publicly acknowledged use of force following the U.N.'s 2008 authorization. ${ }^{10}$ Legal uncertainties surrounding what type of

7. According to the International Maritime Bureau, as of August 2013. See Piracy News \& Figures, ICC COMMERCIAL CRIME SERVICES, http:/www.icc-ccs.org/piracy-reporting-centre/piracy newsafigures (last visited May 17, 2015); see also OFFICER OF THE WATCH, MARITIME PIRACY MON. REP. 2 (Aug. 2013). In June 2014, eleven sailors held hostage for three and a half years were freed. Somali Pirates Release Sailors, AGENCE-FrANCE PRESSE, June 7, 2014, available at http://www.nytimes.com/2014/06/08/world/africa/somali-pirates-release-sailors-held-for-years.html. As recently as October 2014, an additional seven sailors were exchanged for ransom. Somalia: Pirates Release Indian Sailors Held for 4 Years, REUTERS, Oct. 31, 2014, available at http://www.nytimes.com/2014/11/01/world/africa/somalia-pirates-free-indian-sailors-held-for-4years.html. Additionally, one commentator noted in October 2013 that recent conditions in southern Somalia had created the conditions for piracy to resurface. See Currun Singh, Al Shabab Fights the Pirates, N.Y. TIMES, Oct. 22, 2013, http://www.nytimes.com/2013/10/23/opinion/international/alshabab-fights-the-pirates.html.

8. See Lauren Ploch et al., Cong. Research Serv., R40528, Piracy off the Horn of AFrICA 27 (2009); see also Julian E. Barnes, U.S. Military: Somali Pirates Expanding Their Range, WALL ST. J., Jan. 26, 2011, http://blogs.wsj.com/washwire/2011/01/26/us-military-somali-piratesexpanding-their-range. Legislative leaders in the U.S. have also encouraged action ashore. See Ike Skelton, House Armed Services Committee Chairman Skelton Urges President Obama to Fight Piracy by Denying Safe Haven in Somalia, U.S. FED. News SERVICE, Apr. 17, 2009 ("I encourage [President Obama] to pursue these pirates beyond the waters we are currently patrolling and into the safe havens where they are operating. Article I, Section 8 of the U.S. Constitution requires no less. Furthermore, established authorities such as United Nations Security Council Resolutions 1846 and 1851 have expanded the ability of international forces to conduct counter-piracy operations within Somali territory.").

9. S.C. Res. 1851, 9 6, U.N. Doc. S/RES/1851 (Dec. 16, 2008) ("[s]tates and regional organizations for which advance notification has been provided by the TFG to the Secretary-General may undertake all necessary measures that are appropriate in Somalia, for the purpose of suppressing acts of piracy and armed robbery at sea, pursuant to the request of the TFG, .. consistent with applicable international humanitarian and human rights law.”). This authority has been renewed annually. See S.C. Res. 2125, ๆ 12, U.N. Doc. S/RES/2125 (Nov. 18, 2013).

10. Gettleman, supra note 2. Although there have been other uses of force in Somalia related to piracy, they generally fell into the category of hostage rescue versus disrupting pirate activities. See, 
force ashore was authorized, and what law applied to such force, possibly contributed to the delay. ${ }^{11}$

This Article analyzes the international legal framework authorizing and governing the use of force on land in Somalia to eliminate the pirates' means of carrying out lethal attacks at sea. Part I addresses the fundamental question of whether the use of military force against pirates and their bases ashore is legally supportable. Several major justifications are examined, including consent of the sovereign, decisions of the U.N. Security Council, and self-defense. I argue that because the Security Council has authorized "all necessary measures" pursuant to Somali government consent, the use of force in Somalia to accomplish the goal of suppressing piracy at sea is authorized, consistent with the limitations set forth in the applicable Resolutions.

After concluding that the Security Council's mandate includes military force in Somalia, Part II examines what body of law would apply to the practical implementation of such operations. The case of armed pirates' activities ashore is unique in that it may not rise to the level of a traditional armed conflict - the threshold at which International Humanitarian Law (IHL), sometimes referred to as the Law of Armed Conflict (LOAC), would apply. IHL is considered the lex specialis generally applicable to the use of force. ${ }^{12}$ The question of how an armed conflict with groups of pirate-fighters would be characterized is fully explored in this section. I conclude that even if this unique scenario does not rise to the level of an armed conflict, there are significant reasons why IHL should be found to apply to the limited use of force in Somalia. Most importantly, the application of IHL is necessary to give full effect to the

e.g., French Troops Seize Somali Pirates After Hostages are Freed, N.Y. TIMES, Apr. 11, 2008, http://www.

nytimes.com/2008/04/11/world/africa/11iht-yacht.4.11921315.html.

11. See Eugene Kontorovich, International Legal Responses to Piracy off the Coast of Somalia, ASIL InSIGHTS (Feb. 6, 2009), http://www.asil.org/insights090206.cfm; see also ROBIN GEISS \& ANNA Petrig, Piracy and Armed Robbery at Sea: The Legal Framework for Counter-Piracy OPERATIONS IN SOMALIA AND THE GULF OF ADEN 131-34 (2011).

12. There is considerable debate about whether - and how-IHL would displace other legal norms, most notably international human rights law. For the purpose of this Article, I set aside the challenging question of overlap and focus on the potential application of IHL. Even so, some difficulties presented by potential areas of overlap are explored in Part II, infra. See also Oona Hathaway, Which Law Governs During Armed Conflict? The Relationship Between International Humanitarian Law and Human Rights Law, 96 MinN. L. REV. 1883, 1893-912 (2012); U.N. OFF. OF THE High COMmissioner for Human Rights, InTERnATional LEgal Protections of Human Rights In ARMEd Conflict, U.N. Doc. HR/PUB/11/01, U.N. Sales No. E.11.XIV.3 (2011); Francoise J. Hampson, The Relationship Between International Humanitarian Law and Human Rights Law from the Perspective of a Human Rights Treaty Body, 90 INT'L REV. RED CROSS 549, 550 (2008). 
Security Council's decision, at Somalia's request, that force be used in Somalia to suppress piracy.

It is true that pirate attacks off the coast of Somalia continue to recede. ${ }^{13}$ At the same time, reports indicate that suspected pirates and even innocent fisherman are being killed by overeager and untrained security guards embarked on vessels transiting pirate-infested waters. ${ }^{14}$ If the recent ebb of maritime piracy off the coast of Somalia is due to private embarked security teams using unlawful force against pirates, it may be time to rethink any assumption that the use of targeted force ashore is too risky, or less humane. ${ }^{15}$

The use of force ashore naturally carries with it great risks as well. While I briefly note the most significant ones, I set aside as much as possible any broader considerations of policy and strategy. My goal is to propose a framework for how operations can be planned and conducted to satisfy international legal regimes if the use of force ashore meets desired policy ends.

\section{JUSTIFICATIONS FOR THE USE OF FORCE IN SOMALIA}

Depending on the circumstances, at least three possible justifications could support the use of force in Somali land territory to suppress piracy. Before looking at each of these possible justifications in more detail, though, it is worth a brief look at what organized groups of armed pirates in Somalia actually do on dry land.

With the ability to launch attacks up to 1,000 miles off of the Somali coast, the shore-based infrastructure to support sustained piracy operations is robust. ${ }^{16}$ At one point, the North Atlantic Treaty Organization (NATO)

13. See Singh, supra note 7.

14. See Michelle Wiese Bockmann \& Alan Katz, Shooting to Kill Pirates Risks Blackwater Moment, BloOMBERG, May 9, 2012, http://www.bloomberg.com/news/2012-05-08/shooting-to-killpirates-risks-blackwater-moment.html ("According to many interviewed maritime security firms, ship owner groups, lawyers and insurance companies, fear of pirate attacks has increased the likelihood of violent encounters at sea, as untrained or overeager vessel guards have resorted to shooting indiscriminately without first properly assessing the actual threat level. In the process, they have killed both pirates and sometimes innocent fishermen as well as jeopardized the reputation of private maritime security firms with their reckless gun use. Since many of the new maritime security companies that have emerged often also enlist the services of off-duty policemen and former soldiers that saw combat in Iraq and Afghanistan, worries of a 'Blackwater out in the Indian Ocean' have only intensified.").

15. The use of force on board vessels is governed by the flag state's domestic law. See U.N. Convention on the Law of the Sea, art. 94, opened for signature Dec. 10, 1982, 1833 U.N.T.S. 397 [hereinafter UNCLOS]. This would include criminal liability for the unlawful use of force by armed security personnel, but further analysis of this liability is beyond the scope of this Article.

16. David Von Drehle, The Arabia Sea, TIME, Feb. 28, 2011, at 13 (noting that the Somali pirates "have extended their range as far south as Madagascar and as far east as the islands off India."). 
knew of at least nine substantial logistics centers. ${ }^{17}$ The largest, termed "Great Pumpkin" because orange tarps were visible well out into the sea, at one time contained vast numbers of small boats, or skiffs, as wells as whalers and other larger vessels capable of serving as "mother ships"floating logistics bases that organized pirate groups use to extend their reach and to launch attacks farther from shore. ${ }^{18}$ Pirate clans also store consumable supplies ashore in bulk, including barrels of fuel and water, grappling hooks, automatic and semi-automatic weapons, and utility vehicles. $^{19}$

Higher up the pirate organizational chain, financiers and pirate clan leaders direct operations from secure centers, sometimes isolated from the civilian population. $^{20}$ "Somali pirates operate from well-equipped and well-armed bases ashore along the Indian Ocean coast of Central Somalia and Puntland, from the port towns of Caluula, Eyl, Hobyo, and Haradheere." 21 Pirate networks are even reportedly funded via a "stock exchange" located in Haradheere, at which investors can buy or sell shares in upcoming attacks. ${ }^{22}$ Ransom negotiators work from shore, ${ }^{23}$ and the trafficking in weapons - predominantly AKMs, RPG-7s, AK47s, and semiautomatic pistols such as the TT-30, ${ }^{24}$ as well as grenade-launchers-is usually completed ashore. Though it remains controversial, circumstantial evidence has tied pirate clans to Al Shabaab, the Islamic militant group widely considered a terrorist organization. ${ }^{25}$

Pirate operations ashore thus represent a center of gravity that supports their continued attacks on vessels at sea by organized groups of armed pirate-fighters. Disrupting this center of gravity by denying them

17. See Nato Frustrated Amid Somali Piracy Deluge, BBC NEWs (Oct. 22, 2010), http://www.bbc.co.uk/news/world-11609724.

18. Id.; see also Tom Tulloch, The Problem with Pirates, 71 SITREP 3, 5 (2011).

19. Nato Frustrated Amid Somali Piracy Deluge, supra note 17; Tulloch, supra note 18.

20. See U.S. NAT'L Security Council, Countering Piracy off the Horn of Africa: PARTNERSHIP \& ACTION Plan (2008) [hereinafter PARTNERSHIP \& ACTION Plan].

21. Id. at 5 .

22. Bruce Sterling, The Pirate Stock Exchange, WIRED, Dec. 3, 2009, http://www.wired.com/ beyond_the_beyond/2009/12/the-pirate-stock-exchange.

23. See United States v. Ali, 870 F. Supp. 2d 10 (D.C. Cir. 2012).

24. See Somali Pirates Killed “Legally”, BBC NEws (Dec. 19, 2008), http://news.bbc.co.uk/ 2/hi/uk_news/england/devon/7791236.stm.

25. See, e.g., Jonathan Saul and Camila Reed, Shabaab-Somali pirate links growing: UN adviser, REUTERS (Oct. 20, 2011), http://www.reuters.com/article/2011/10/20/ozatp-somalia-shabaab-piratesidAFJOE79J0G620111020; see also Richard Lough, Piracy ransom cash ends up with Somali militants, REUTERS (Jul. 6, 2011), http://www.reuters.com/article/2011/07/06/somalia-piracy-idUSLDE7650 U320110706; Al Qaeda Urges Somalis To Attack Ships, CBS (Apr. 16, 2009), http://www.cbsnews.com /8301-503543_162-4949488-503543.html; but see Singh, supra note 7. 
logistics and operating bases ashore would likely cripple their ability to continue to sustain attacks at sea.

Although the number of recently reported pirate attacks is down significantly, there is little evidence that the Somali pirates' capacity for continued violence has been diminished. ${ }^{26}$ Indeed, armed pirates are still holding hostages ashore and could re-commence attacks if the widespread deployment of armed security on board transiting merchant vessels is abated. $^{27}$ The Somali government has continued to request international support, most recently in November 2013. ${ }^{28}$ The government's consistent requests for support from 2008 through the present, even in the face of an apparent decline in piracy attacks at sea, underscore their inability to deal with the militia-type lawlessness of the armed groups of pirates, including the holding of hostage-prisoners ashore. ${ }^{29}$ Thus, a legal framework for possible action ashore is an important part of any effective long-term antipiracy strategy.

There are at least three possible justifications under international law that would support the use of force in Somali land territory to suppress piracy. First, the U.N. Security Council could act - and indeed has actedto authorize such force. ${ }^{30}$ Because this authorization is still currently in effect and has presumably been relied upon by states to support military operations, it is the most relevant to this analysis. ${ }^{31}$

This current authorization is further legitimized by a second, ongoing justification of consent on the part of the Somali government. ${ }^{32}$ Though

26. See Singh, supra note 7.

27. $I d$.

28. See S.C. Res. 2125, supra note 9, at 2 (“... noting the several requests from Somali authorities for international assistance to counter piracy off its coast, including the letter of 12 November 2013, from the Permanent Representative of Somalia to the United Nations expressing the appreciation of Somali authorities to the Security Council for its assistance, expressing their willingness to consider working with other States and regional organizations to combat piracy and armed robbery at sea off the coast of Somalia, and requesting that the provisions of resolution 2077 (2012) be renewed for an additional twelve months.").

29. Throughout this Article, "Somalia" and "Somali government" refer to the internationally recognized sovereign authority of the state of Somalia. Prior to August 20, 2012, this was the Transitional Federal Government (TFG), which is referenced in Resolution 1851. See TRANSITIONAL Federal Charter for the Somali Republic, Feb. 2004. In 2012, the Federal Republic of Somalia was created by a new constitution. See Provisional Constitution of the FEDERAL RePUBLIC OF Somalia, Aug. 1, 2012. Both have the same functional authority under international law as the recognized sovereign government of Somalia, and are treated the same for purposes of this Article.

30. S.C. Res. 1851, supra note 9, ๆ 6; S.C. Res. 2125, supra note 9, 110.

31. S.C. Res. 1851, supra note 9, ๆ 6; S.C. Res. 2125, supra note 9, ๆ 10; see also Gettleman, supra note 1.

32. See S.C. Res. 1851, supra note 9, 10 ("[the Council] affirms further that such authorizations have been provided only following the receipt of the 9 December 2008 letter conveying the consent of 
Somalia could also grant consent to third-party states on an ad hoc basis under its sovereign authority and consistent with its international legal obligations, there are no indications that it has done so. Instead, the current framework seems to be consent-based, but ratified by the Security Council under its Chapter VII authority.

A third potential justification, self-defense, does not seem to have been proposed or debated in the situation in Somalia on any significant scale. It could potentially arise, however, in the more limited case of hostage rescue operations. Each of these potential justifications will be examined in turn.

\section{A. U.N. Security Council action under Chapter VII}

The U.N. Security Council has the power to determine "the existence of any threat to the peace, breach of the peace, or act of aggression," and to "decide what measures shall be taken ... to restore international peace and security." "33 If the Council deems the threat significant enough, it may authorize "action by air, sea, or land forces as may be necessary to maintain or restore international peace and security." 34

The Security Council has addressed the issue of piracy off the coast of Somalia at least twelve times, beginning with Resolution 1816 in $2008 .^{35}$ This and other early resolutions are widely considered not to have created any significant new international legal authority, and mostly call on states to take actions that were already authorized under international law. ${ }^{36}$ Resolution 1816 did include authority for states cooperating with the Somali government to enter Somali territorial waters "for the purpose of repressing acts of piracy and armed robbery at sea," but it did not include any mention of Somali land territory. ${ }^{37}$ Thus, despite its seemingly broad

the [Somali Transitional Federal Government]"); see also Tullio Treves, Piracy, Law of the Sea, and Use of Force: Developments off the Coast of Somalia, 20 EUR. J. INT'L L. 399, 406 (2009).

33. U.N. Charter art. 39, $\uparrow 1$.

34. U.N. Charter art. 42, $\uparrow 1$.

35. S.C. Res. 1816, U.N. Doc. S/RES/1816 (June 2, 2008); S.C. Res. 1838, U.N. Doc. S/RES/1838 (Oct. 7, 2008); S.C. Res. 1846, U.N. Doc. S/RES/1846 (Dec. 2, 2008); Error! Bookmark not defined.S.C. Res. 1897, U.N. Doc. S/RES/1897 (Nov. 30, 2009); S.C. Res. 1918, U.N. Doc. S/RES/1918 (Apr. 27, 2010); S.C. Res. 1950, U.N. Doc. S/RES/1950 (Nov. 23, 2010); S.C. Res. 1976, U.N. Doc. S/RES/1976 (Apr. 11, 2011); S.C. Res. 2015, U.N. Doc. S/RES/2015 (Oct. 24, 2011); S.C. Res. 2020, U.N. Doc. S/RES/2020 (Nov. 22, 2011); S.C. Res. 2077, U.N. Doc. S/RES/2077 (Nov. 21, 2012); S.C. Res. 1851, supra note 9; S.C. Res. 2125, supra note 9.

36. See S.C. Res. 1846, supra note 35 , 1, ("Further reaffirming that international law, as reflected in [UNCLOS], sets out the legal framework applicable to combating piracy and armed robbery at sea"). This affirmation can also be found in S.C. Res. 1851, supra note 9, at 1, S.C. Res 1897 , supra note 35 , at 1, and S.C. Res 1918, supra note 35, at 1. See also GEISS \& PETRIG, supra note 11, at 72-3.

37. S.C. Res. 1816 , supra note 35 , 97. 
language, the Council's first steps did not empower nations to do much beyond what they already could, and certainly did not purport to take any action with respect to Somali territory. ${ }^{38}$ The authorizations were effectively a call to states to take the full measures within their power to fight piracy at sea. ${ }^{39}$

\section{Resolution 1851: Authorization and Restrictions of Operative Paragraph 6}

In December 2008, the Security Council greatly expanded its authorization by taking action under Chapter VII of the U.N. Charter. ${ }^{40}$ Resolution 1851 authorized states to take counter-piracy action on Somali land territory, and it authorized "all necessary measures" to do so, connoting military force. ${ }^{41}$ The specific authorization, though, came with important caveats, set forth in Operative Paragraph 6:

"States and regional organizations... for which advance notification has been provided by the TFG [Transitional Federal Government of Somalia] to the Secretary-General may undertake all necessary measures that are appropriate in Somalia, for the purpose of suppressing acts of piracy and armed robbery at sea, pursuant to the request of the TFG, ... consistent with applicable international humanitarian and human rights law. ${ }^{42}$

While Paragraph 6 clearly broadened enforcement measures to Somali land territory, there has been debate as to how far that broadening was intended to go, and what specific measures are in fact authorized. ${ }^{43}$ States may undertake "all necessary measures"-_text that is commonly accepted

38. See Geiss \& Petrig, supra note 11, at 71-72 (explaining that S.C. Res. 1846 is widely interpreted to have expanded enforcement measures authorized on the high seas into Somali territorial waters).

39. Id. One area in which authority was expanded was the entry into Somali territorial waters. States responded to this charge through international naval action. See Res. 1950 Report, supra note 5 , ฯ 66.

40. S.C. Res. 1851, supra note 9, at 2.

41. Id., See also GEISS \& PETRIG, supra note 11, at 83.

42. S.C. Res. 1851, supra, note 9, 6 (emphasis added).

43. The debate surrounding the adoption of S.C. Res. 1851 indicated disagreement on how exactly the land-based authorization would be worded, but it is generally accepted that the authorization includes Somali land territory and the airspace above it. See Kontorovich, supra note 11 (stating that Resolution 1851 "extend[s] the authorization of military force to land-based operations in Somalia mainland") (internal citation omitted). See also Douglas Guilfoyle, The Laws of War and the Fight against Somali Piracy: Combatants or Criminals?, 11 Melbourne J. OF INT'L L., 1, 7 (2010); GeISS \& PETRIG, supra note 11, at 82, 131-34; but see Security Council Passes New Resolution on Somalia Piracy, AgenCe France-Presse ( Dec. 17, 2008), available at http://www.aaj.tv/2008/12/securitycouncil-passes-new-resolution-on-somalia-piracy/ ("to overcome objections from countries such as Indonesia, the sponsors dropped an earlier reference in the text to "ashore" or "including in Somali airspace."). 
to include the authorization for military force - but in this case with several express and implied restrictions. ${ }^{44}$

First, advance notification must be "provided by the [Somali federal government] to the Secretary-General."45 Besides the express requirement that the Somali government notify the Secretary-General prior to the commencement of any operation within Somali territory, the provision also could be interpreted to include an implied requirement that the Somali government must concur with each action taken under the paragraph. ${ }^{46}$ Presumably, if the TFG does not concur, it need not notify the SecretaryGeneral and the proposed measures would therefore not come to bear. Of note, there is nothing in the Resolution requiring the Somali government to make any particular notification, but the notification necessarily must be made in order for the authority contained in the Resolution to become effective. $^{47}$

Second, measures taken must be "appropriate in Somalia" and "for the purpose of suppressing acts of piracy and armed robbery at sea." 48 It is not clear whether the mandate that the action be "appropriate" adds any substantive restriction, especially given that the Somali government must implicitly approve any operation. The requirement that action on land likewise be linked to the suppression of piracy at sea is very general and consistent with the broadened mandate of Paragraph 6.

Finally, measures taken must be "consistent with applicable international humanitarian and human rights law." $" 49$ The reference to both IHL, as well as the more generally applicable human rights law (HRL), is significant. It is an implicit recognition that, given the gravity of the threat to international security that piracy poses, there may be limited situations in which IHL would apply to the "all necessary measures" authorized

44. See Alex Conte, Security In The 21st Century: The United Nations, Afghanistan AND IRAQ 155-57 (2005); see also GEISS \& PETRIG, supra note 11, at 83. Additionally, though not currently at issue, the authorization was set to expire after twelve months from the date of adoption of resolution 1851 . See S.C. Res. 1851 supra note 9, 96 . It has subsequently been extended annually, most recently in November 2013 for an additional twelve months, and has not lapsed since originally implemented. See also S.C. Res. 2125, supra note 9, at 2 (noting that the Somali government provided continued consent in a letter dated November 12, 2013).

45. S.C. Res. 1851 supra note 9, $₫ 6$.

46. S.C. Res. 1851 also contains a further restriction limiting it to "cooperating states." Id. This section analyzes the requirement for notification to the Secretary-General by the TFG, which I consider to be substantively the same. The precise mechanics of this process are not clear, and how they were executed in practice during the EUNAVFOR use of force has not been made publicly available.

47. Id.

48. Id. ๆ 6 .

49. Id. 
ashore. ${ }^{50}$ Because IHL is the lex specialis that generally applies to the use of force during times of armed conflict, ${ }^{51}$ the Security Council's reference to it implies that at least some use of military force was envisioned pursuant to the authority granted in Paragraph 6. The inclusion of IHL would otherwise have no practical effect. The body of law that actually applies to measures taken against pirates depends on several factors and is analyzed in Part II.

\section{Other indications that Resolution 1851 authorizes military force}

In addition to the "all necessary measures" authorization contained in Paragraph 6, several other factors support an interpretation that the Security Council intended to authorize the use of military force ashore. ${ }^{52}$

First, the U.N. published Resolution 1851 by heralding that the Security Council "authorizes states to use land-based operations in Somalia." 53 Paragraph 2 of that Resolution permits, without geographic restriction, the "seizure and disposition of boats, vessels, arms and other related equipment" when there are reasonable grounds for suspecting their use in piracy. ${ }^{54}$ This implies that destruction is also permissible, particularly if seizure is impractical. The use of the term "disposition" implies that the seizing state can dispose of the materiel seized lawfully, ${ }^{55}$ including destroying it remotely on land. ${ }^{56}$ The text of Resolution 1851,

50. Some have maintained that the reference to IHL "appears to be a savings clause included out of an abundance of caution." See, e.g., Guilfoyle, supra note 43, at 7 (arguing that the use of "applicable" refers to the international humanitarian law that would otherwise apply). Given that force on land in Somalia was within the scope of authority of Resolution 1851, a more persuasive reading would be to give the Council's words operative effect in the context of what actions were being authorized versus explaining them away or dismissing them as a mere contingency.

51. See Hampson, supra note 12.

52. S.C. Res. 1851, supra note 9, $₫ 6$.

53. See Press Release, Security Council, Security Council Authorizes States to Use Land-Based Operations in Somalia, as Part of Fight Against Piracy Off Coast, Unanimously Adopting 1851, U.N. Press Release SC/9541 (Dec. 16, 2008) [hereinafter Press Release SC/9541].

54. See S.C. Res. 1851, supra note 9, 2 (calling on states to deploy naval vessels and military aircraft, but not specifically ground forces). Even so, Paragraph 2 calls upon states "to take part actively in the fight against piracy... consistent with this resolution and international law," which recognizes the creation of additional authority in Res. 1851. Id. It also authorizes "seizure and disposition of boats, vessels, arms and other related equipment used in the commission of piracy and armed robbery at sea off the coast of Somalia, or for which there are reasonable grounds for suspecting such use," notably without geographic reference. Id. Therefore, destroying "boats, vessels, arms and other related equipment" in Somali territory is consistent with Paragraph 2.

55. Throughout this article, "materiel" is used to refer to pirates" "boats, vessels, arms and other related equipment" referenced in S.C. Res. 1851, supra note 9, $\ 2$.

56. For a discussion of the standards for seizure and destruction of pirates' materiel under UNCLOS and S.C. Res. 2077, see Matteo Crippa, Liability for the Destruction of Suspected Pirate Skiffs?, Communis Hostis OMNIUM (Jan. 3, 2013), http://piracy-law.com/2013/01/04/is-there-a- 
therefore, authorizes at least the destruction of the materiel needed by pirates to execute their violent acts.

Second, the Council members' explanations of votes offer strong support for the notion that military force on land is authorized. The United Kingdom representative, David Miliband, explained that " $t]$ he authorization conferred by Paragraph $6 \ldots$ enabled States and regional organizations to act with force, if necessary, on land in Somalia." 57 Additionally, using the language of IHL, he further noted that the "use of force, however, must be both necessary and proportionate." 58 Representative Jan Grauls of Belgium noted that the "resolution allowed combat against piracy both on sea and land. ${ }^{59}$

Even those wary of the relevant provision acknowledged that it allowed the use of force on land. Representative Dumisani Kumalo of South Africa "expressed concern over the provision in the resolution that allowed for States to conduct land-based operations against piracy, saying there was a danger that innocent Somalis could fall victim to those operations." ${ }^{\prime 60}$ This statement suggests that Council members considered unintended loss of innocent life consistent with the doctrine of doubleeffect. $^{61}$

For the United States, Secretary of State Condoleezza Rice stated that "pursuing pirates on land would have a significant impact," and that "[m]aritime operations alone were insufficient for combating piracy." 62 Some Council members expressed a further desire for a U.N. peacekeeping force in Somalia with both "maritime and land elements." 63 Council members were notably impacted by Somalia's strong support for Resolution 1851, underscoring the resolution's international legitimacy. ${ }^{64}$

Third, the application of force ashore by the European Union in the spring of 2012, coupled with a lack of international protest and implied ratification by both the Somali government and the Security Council, add a

liability-for-the-destruction-of-suspected-pirate-skiffs/.

57. Press Release SC/9541, supra note 53.

58. Id.

59. Id.

60. Id.

61. The doctrine of double-effect allows for the possibility of harm as an unintended consequence of the pursuit of a just or lawful course of action. See SHADIA B. DRURY, Aquinas AND MOdERNITY: The Lost Promise of NATURAL LAw 67-68 (Rowman \& Littlefield, 2008).

62. Press Release SC/9541, supra note 53.

63. Id. ("Egypt looked forward to having the Security Council study the option of deploying a United Nations peacekeeping force in Somalia, to act as a "safety valve," with the possibility of exploring ways to enhance the peacekeeping force with both "maritime and land elements.").

64. Id. See also GEISS \& PETRIG, supra note 11 , at 84-85. 
highly persuasive historical gloss to the text of Resolution 1851. The EUNAVFOR's destruction of several fiberglass skiffs on the beach in Haradheere was widely reported in May of 2012. ${ }^{65}$ Months later, the Somali government requested continued assistance from the international community, and the Council passed Resolution 2077 in November 2012, renewing the authorization in Paragraph 6 of Resolution 1851 for a further twelve months. ${ }^{66}$ This implied ratification of military action by both the Somali government and the Security Council compels an interpretation that the use of force on land is authorized, at least with regard to the destruction of "boats, vessels, arms and other related equipment" when there are reasonable grounds for suspecting their use in piracy. ${ }^{67}$

Despite this evidence, some commentators have been reticent to acknowledge the full force of the Security Council's decision. Some have concluded that Resolution 1851 merely continues a law enforcement paradigm, and that Paragraph 6 possibly "envisages operations in which external actors engage in law enforcement activities in the territory of a failed state. ...",68 One commentator noted that the "shift from a military to a law-enforcement paradigm is particularly pronounced with Resolution 1851."69 While Resolution 1851 does speak to increased cooperation and action in the realm of prosecution, it seems that the weight of the evidence supports the conclusion that military force was envisioned as a necessary measure for combating piracy at sea. ${ }^{70}$

65. See, e.g., Gettleman, supra note 1.

66. S.C. Res. 2077, supra note 35, 12. This authorization was further renewed in S.C. Res. 2125, supra note 9.

67. S.C. Res. 1851, supra note 9, ๆ 2; S.C. Res. 2077, supra note 35, ๆ 10.

68. See GeISs \& PETRIG, supra note 11, at 132-33. Geiss and Petrig refer to the "overall aim of ensuring the long term security of international navigation off the coast of Somalia," and the emphasis on effectively investigating and prosecuting piracy as a crime as support for the argument that the law enforcement paradigm was confirmed in Resolution 1851. Id. Though they acknowledge that counterpiracy operations "could eventually reach the threshold of non-international armed conflict, thereby triggering the application of [IHL]," they fail to acknowledge the strong indications that force was authorized. Id. Resolution 1851 was not the first Security Council action addressing piracy off the coast of Somalia. Clearly, Paragraph 6 indicates that more aggressive action needed to be taken. See S.C. Res. 1851, supra note 9. Further, the Resolution's purpose of "suppressing acts of piracy and armed robbery at sea," does not particularly support the argument that the Security Council "confirmed the law enforcement paradigm." Id. Instead, the argument likely supported by that premise is that the Security Council recognized the link in Paragraph 6 between action ashore and suppressing acts of piracy at sea, and that it chose to take more decisive action against pirates.

69. See Douglas Guilfoyle, Piracy off Somalia: a sketch of the legal framework, BLOG OF THE EUROPEAN JOURNAL OF INTERNATIONAL LAW (Apr. 20, 2009), http://www.ejiltalk.org/piracy-offsomalia-a-sketch-of-the-legal-framework.

70. Id. Other scholars have significantly limited their analysis of the full implications of Resolution 1851. See, e.g., Milena Sterio, International Law in Crisis: Piracy Off the Coast of Somalia, 44 CASE W. RES. J. INT’L L. 291, 295 (2011) (“. . . to chase pirates after the original piracy encounter, 
Because of the plain language of Resolution 1851, the clearly expressed intent of the Security Council members that the text conveys the authorization to use force, and the implied ratification of forcible measures actually taken, the use of authorized force in Somalia is consistent with the limitations set forth in the Resolution. ${ }^{71}$

\section{B. Consent of the sovereign}

Within its territory, a sovereign state-Somalia in this case - generally retains ultimate authority under international law and could invite other states to cooperate or to act independently in a wide range of scenarios. ${ }^{72}$ Under international law, the sovereign retains ultimate accountability under this scenario to ensure that applicable human rights norms are followed. ${ }^{73}$

Outside of that broad and general restriction, the sovereign retains control to determine the character of international assistance taken pursuant to its consent. This becomes relevant when looking at the law applicable to any action taken under such consent, as we will see in the following section on the law applicable to the use of force in Somali territory.

In addition to stipulations, Somalia could determine whether such actions were strictly law enforcement in nature, or assist in determining

and to even enter Somali land.”)

71. With the caveats that are listed in Paragraph 6, as described S.C. Res. 1851, supra note 9.

72. Although not without its problems, the perception that the Somali government is nonfunctioning is not widely accepted. The new Somali Federal Government took over from a transitional government in August 2012, and has stepped into the previous role of the TFG. While previous Security Council Resolutions referenced the TFG, the most recent resolution only references the "new Somali government." See Somali Leaders Back New Constitution, BBC NEws (Aug. 1, 2012), http://www.bbc. co.uk/news/world-africa-19075685; see also James Fergusson, Somalia: A Failed State Is Back From The Dead, THE INDEPENDENT, Jan. 13, 2013, http://www.independent.co.uk/news/world/africa/somaliaa-failed-state-is-back-from-the-dead-8449310.html. So, while this section applies Security Council action to Somalia only in the broader context, the framework for analysis could be looked at even more generally. Land-based piracy networks have existed before, and there is some evidence that they are becoming more prevalent in different parts of the world, though admittedly not on the scale seen in the Horn of Africa.

73. See Ashley S. Deeks, Consent to the Use of Force and International Law Supremacy, 54 HARV. INT'L LAW J. 1, 6-10 (2013); see also U.N. Special Rapporteur on Extrajudicial, Summary or Arbitrary Executions, Study on targeted killings, U.N. Doc. A/HRC/14/24/Add.6 (May 28, 2010) ("The proposition that a State may consent to the use of force on its territory by another State is not legally controversial. But while consent may permit the use of force, it does not absolve either of the concerned States from their obligations to abide by human rights law and IHL with respect to the use of lethal force against a specific person. The consenting State's responsibility to protect those on its territory from arbitrary deprivation of the right to life applies at all times. A consenting State may only lawfully authorize a killing by the targeting State to the extent that the killing is carried out in accordance with applicable IHL or human rights law.”) citing International Covenant on Civil and Political Rights art. 6, Dec. 16, 1966, 999 U.N.T.S. 171 [hereinafter ICCPR]; Resolution on the Protection of Human Rights and Fundamental Freedoms While Countering Terrorism, G.A. Res. 51/191, 』 1, U.N. Doc. A/Res/51/191 (Dec. 16, 1996). 
whether pirates constituted an armed insurgency, depending on the relevant facts. Somalia could clarify the relevance of Somali law to the action against pirate camps, and also the status of individuals associated with foreign armed forces and governments in Somalia, including their potential liability under Somali law for acts taken that don't go as planned.

While there is no current indication that Somalia has provided specific consent to any individual state to use force ashore to suppress piracy, its consent provided the foundation for Resolution $1851 .^{74}$ The Security Council specifically referenced this consent in the Resolution, adding that its authorization under Chapter VII was not intended to create any new norm of customary international law. ${ }^{75}$ Thus, consent is currently in place, but it is exercised via the Security Council rather than potentially more cumbersome bilateral or multilateral agreements with other states.

\section{Self-defense}

Though the Security Council has authorized the use of force ashore in Somalia, force could still be justified in the absence of such authorization under certain limited circumstances. If a state's military forces or vessels sailing under its flag were subject to an armed attack, it would have the right under international law to respond with necessary and proportional force in self-defense. $^{76}$ Although the U.N. Charter forbids the use of force, ${ }^{77}$ nothing impairs the right to act in self-defense "if an armed attack occurs against" a member state. ${ }^{78}$ Necessary and proportional force could include the authority to take action to eliminate the threat, as long as the pirates are still demonstrating an imminent hostile intent. ${ }^{79}$

More difficult questions arise when pirates operating ashore present an imminent threat to U.S. vessels and U.S. persons at sea. ${ }^{80}$ The

74. Press Release SC/9541, supra note 53; see also S.C. Res. 1851, supra note 9, ๆ 6.

75. Press Release SC/9541, supra note 53; see also Treves, supra note 32, at 406 ("Indeed, the activities purportedly 'authorized' by the Security Council in light of the coastal state's authorization could also be conducted in the absence of a Security Council resolution adopted within the framework of Chapter VII.").

76. U.N. Charter art. 51.

77. U.N. Charter art. 51, $₫ 4$.

78. U.N. Charter art. 51.

79. See Mohammed Saif-Alden Wattad, Resurrecting "Romantics at War": International SelfDefense in the Shadow of the Law of War-Where Are the Borders?, 13 ILSA J. INT'L \& COMP. L. 205, 219 (2006) ("[t]he permissible use of force is limited to acts of state self-defense, which can be performed only in response to an armed attack, including an imminent threat to amount to an armed attack.").

80. See Daniel Pines, Maritime Piracy: Changes in U.S. Law Needed to Combat This Critical National Security Concern, 36 SEATTLE U. L. REV. 69, 81 (2012) ("In just the past few years, pirates have attacked U.S. vessels on several occasions. The attack on the Alabama described in the 
resolution of these complex questions of self-defense is beyond the scope of this analysis. The issue is only highlighted here as a possible justification for the use of force under very narrow circumstances. ${ }^{81}$ As of now, self-defense has not been advanced as a viable justification for the use of force on land to suppress piracy, and there is no indication that the EUNAVFOR relied on self-defense to support recent actions taken ashore. $^{82}$

Indeed, under international law, a sovereign state retains the primary responsibility and authority for the maintenance of law and order in its land territory. ${ }^{83}$ Issues such as pursuit or the use of force ashore, in a selfdefense scenario, would likely only arise in a hostage-rescue or ship-rescue scenario when the sovereign was either unable or unwilling to take the necessary action to eliminate the threat posed to the victim-state's forces, vessels, or nationals. ${ }^{84}$

Thus, although there are at least three possible justifications under international law that would support the use of force in Somali land territory to suppress piracy, the Security Council's action to authorize force (with various restrictions) is the most relevant to the current situation. ${ }^{85}$ The next section analyzes what body of law would apply to give practical

introduction is just one example. Other examples include two separate pirate attacks on U.S. military vessels in 2010 near Somalia, where the pirates in both cases believed the vessels to be merchant ships." (internal citations omitted)). Additionally, the notion that an "imminent threat" justifies the use of force in self-defense is not without controversy. See, e.g., Daniel Bethlehem, Principles Relevant to the Scope of a State's Right of Self-Defense Against an Imminent or Actual Armed Attack by Non-State Actors, 106 AM. J. INT'L L. 769 (2012).

81. Beyond response to an armed attack, the special case of hostage rescue may serve as an additional narrow justification for the use of force ashore to rescue nationals held as hostages, but again, only if the sovereign were unable or unwilling to adequately protect the hostages or deal with the situation. See Oscar Schachter, International Law in Theory and Practice: General Course in Public International Law, 178 RECUEIL DES COURS 145 (1982) ("General Scranton, the U.S. representative to the UN in 1976, stated, in the context of a debate about Israel's use of force in Uganda to rescue its nationals, "Israel's action in rescuing the hostages necessarily involved a temporary breach of the territorial integrity of Uganda. Normally, such a breach would be impermissible under the Charter of the United Nations. However, there is a well-established right to use limited force for the protection of one's own nationals either from an imminent threat of injury or death in a situation where the state in whose territory they are located is either unwilling or unable to protect them.").

82. See Gettleman, supra note 1 .

83. See Ashley S. Deeks, "Unwilling or Unable": Toward A Normative Framework for Extraterritorial Self-Defense, 52 VA. J. INT'L L. 483, 504 (2012) (“In the best-case scenario, the territorial state is willing and able to suppress the threat. In that case, the victim state achieves its goal without expending resources, and the territorial state preserves its sovereignty.").

84. See id. at 489 ("The fact that states currently are acclimated to using the "unwilling or unable" test suggests that any other test would have to overcome a high bar to become the preferred test, a hurdle no other option is poised to meet.")

85. S.C. Res. 1851, supra note 9, ๆ 2; S.C. Res. 2125, supra note 9. 
effect to the Council's decision.

\section{LAW APPLICABLE TO THE USE OF FORCE IN SOMALIA}

As described above, the U.N. Security Council has authorized the use of force in Somali territory "for the purpose of suppressing acts of piracy and armed robbery at sea." ${ }^{\prime 66}$ The use of such force in the territory of another sovereign state must be undertaken pursuant to law-but what law? This section addresses whether international humanitarian law applies to the use of force ashore in Somalia to carry out the mandate of Security Council.

The conclusion is not straightforward. Depending on how U.N. member states undertake a complex and fact-intensive analysis, the situation may or may not rise to the level of an armed conflict. IHL clearly applies during armed conflict. ${ }^{87}$ But notwithstanding such a conclusion, this section argues that IHL should apply in any case to this "gray zone" conflict. The Security Council is competent to declare IHL applicable, and IHL is the lex specialis that is best suited to giving practical effect to the Council's decision while ensuring humanitarian protections.

According to Resolution 1851, enforcement measures taken in Somalia must be "consistent with applicable international humanitarian and human rights law." ${ }^{88}$ It was noted in Part I that this reference to both IHL, the law that applies during armed conflict, as well as the more generally applicable human rights law, is significant because it implies that force is authorized. ${ }^{89}$ It is also significant, though, for its plain-language invocation of "applicable IHL" to "all necessary measures" authorized ashore. ${ }^{90}$ At the same time, the invocation of "human rights law" cannot be ignored, and I note potential areas of overlap below.

We must first determine how to characterize the ongoing conflict in Somalia and off its coast between the organized groups of armed piratefighters on one side, ${ }^{91}$ and the U.N. member states carrying out the Security

86. See S. C. Res. 1851, supra note 9; Hampson, supra note 12.

87. See Hampson, supra note 12, at 550.

88. S. C. Res. 1851, supra note 9.

89. See also GeISS \& PETRIG, supra note 11, at 131-32.

90. S. C. Res. 1851, supra note 9 , 6 .

91. Throughout this section the term "pirate-fighter" refers to a member of an organized armed network of sea-going pirates and shore-based fighters, including their leaders, financiers, facilitators and hostage-keepers ashore, the captains of "motherships" and logistics suppliers at sea, and the seafarers who launch attacks. Though the full extent of Somali pirate-fighter coordination and organization is disputed (and analyzed below), this shorthand is merely used to distinguish organized and networked pirates who are managed ashore from the more straightforward definition of piracy as an international crime under UNCLOS, supra note 15, art. 101. 
Council's mandate on the other. This question gives rise to three potential scenarios.

First, a non-international armed conflict (NIAC) could be found to exist, thus clearly invoking "applicable IHL." ${ }^{92}$ Second, there might be a scenario in which the hostilities fall short of a NIAC, but IHL is nonetheless determined to apply. Finally, if IHL were determined not to apply, the military force authorized by the Security Council would need to be governed by other existing law, including human rights law and Somali domestic law. This latter case may present gaps that prevent the full mandate of the Council from being realized.

I address each of these scenarios in turn. Additionally, throughout the analysis I examine how both sets of legal frameworks present challenges, and suggest some ways to overcome those challenges.

\section{A. If a NIAC were to exist, IHL would clearly apply}

Notwithstanding any legal justification for the use of force, IHL would normally only apply to the use of such force if the situation falls into one of two "law triggering" scenarios-international armed conflict (IAC), or NIAC. ${ }^{93}$ IAC can quickly be dismissed because it presupposes the use of armed force between two or more states. ${ }^{94}$ Even though U.N. member states might be using force in Somalia, any use of such force would be aligned with the sovereign government of Somalia, not against it. ${ }^{95}$ Member states would be acting with the consent of the Somali government against a non-state group in their territory, ${ }^{96}$ which could be considered a

92. As a subset of this scenario, the organized pirate-fighters could be associated with an existing, already-recognized NIAC in Somalia, that is, Al Shabaab. This scenario is explored in Section B.2, infra.

93. See Articles 2 and 3 common to the four Geneva Conventions of 1949 [hereinafter Common Article 2, Common Article 3]. Geneva Convention for the Amelioration of the Conditions of the Wounded and Sick in Armed Forces in the Field art. 3, opened for signature, Aug. 12, 1949, 6 U.S.T. 3114, 75 U.N.T.S. 31; Geneva Convention for the Amelioration of the Conditions of the Wounded and Sick and Shipwrecked Members of Armed Forces at Sea art. 3, opened for signature, Aug. 12, 1949, 6 U.S.T. 3217, 75 U.N.T.S. 85; Geneva Convention Relative to the Treatment of Prisoners of War art. 3, opened for signature, Aug. 12, 1949, 6 U.S.T. 3316, 75 U.N.T.S. 135; Geneva Convention Relative to the Protection of Civilian Persons in Time of War art. 3, opened for signature, Aug. 12, 1949, 6 U.S.T. 3516, 75 U.N.T.S. 287.

94. See Common Article 2, supra note 93.

95. Though the Security Council has consistently authorized such measures "in Somalia," they have always been done pursuant to the request of the Somali government. See S.C. Res. 2125, supra note 9.

96. Indeed, Resolution 1851 implies that the Somali government must consent to specific actions taken ashore in their territory. See S. C. Res. 1851, supra note 9, $₫ 6$ (noting that all necessary measures are authorized, inter alia, "for which advance notification has been provided by the TFG to the Secretary-General"). 
NIAC if certain conditions are met. If a NIAC were to exist, the body of IHL applicable in that type of conflict clearly would apply.

This section first examines the factors used to determine the existence of a NIAC. Second, it turns to some challenges in applying the existing NIAC framework to the unique scenario of armed, land-based groups of pirate-fighters in Somalia. Finally, if the IHL applicable to NIAC is found to apply to the conflict, this section briefly addresses how the most relevant principles of that body of IHL would be applied.

\section{Is there a NIAC?}

Whether a NIAC exists is a question of fact. ${ }^{97}$ Under the Geneva Conventions, non-international armed conflicts are those "not of an international character occurring in the territory of one of the High Contracting Parties...."98 Following calls for greater clarity, this definition was significantly refined with the entry into force of Additional Protocol II (AP II) in 1978. ${ }^{99}$ Under that treaty, a NIAC would only be found to exist if a conflict occurring within a state is between its forces and "other organized armed groups which, under responsible command, exercise such control over a part of its territory as to enable them to carry out sustained and concerted military operations ...."100 Further, AP II specifically does not apply to "situations of internal disturbances and tensions, such as riots, isolated and sporadic acts of violence and other acts of a similar nature, as not being armed conflicts."

Strictly under the AP II definition, the Security Council's authorized force against organized armed pirates in Somalia would likely fall short of the criteria for a NIAC. ${ }^{102}$ It would hit several wickets, though. Because they are hierarchically organized, pirate-fighter networks might be considered "organized armed groups" who operate from discrete bases

97. See Int'L L. Assoc., Final Report on the MEANing of ARmed Conflict in INTERNATIONAL LAW 33 (2010).

98. See Common Article 3, supra note 93.

99. See Anthony Cullen, Key Developments Affecting the Scope of Internal Armed Conflict in International Humanitarian Law, 183 MIL. L. REV. 66, 91-92 (2005), citing INT'L COMM. OF THE RED Cross, COMMENTARY ON THE AdDitional Protocols of 8 June 1977 to the Geneva CONVENTIONS OF 12 August 1949, 1325 (1987).

100. Additional Protocol II to the Geneva Conventions of 12 August 1949, and Relating to the Protection of Victims of Non-International Armed Conflicts, adopted 8 June 1977, entered into force 7 Dec. 1978, U.N. Doc. A/32/144 Annex II, 1125 U.N.T.S. 609 [hereinafter AP II].

101. Id.

102. While Somalia is not a party to AP II, many of its provisions are considered to be customary international law. Additionally, the obligations of U.N. member states under AP II would possibly be implicated by their participation in any NIAC. For the purpose of this analysis, I assume that IHL would apply to any NIAC occurring in Somalia. 
ashore. ${ }^{103}$ Pirates systematically launch coordinated attacks on merchant ships with tactics and weapons that could be considered as part of "sustained and concerted military operations." "104 Additionally, piratefighters don't clearly invoke any of the scenarios specifically excepted from the AP II definition. There is no significant internal disturbance; rather, their force in attacking ships is dedicated, directed, and lethal. ${ }^{105}$ Their violence is not "isolated and sporadic"-indeed, even ashore, their keeping of hostage-prisoners is protracted and planned. ${ }^{106}$

But there are significant challenges to such a characterization. The definition of NIAC espoused in AP II, by its text, applies to organized armed groups that fight the government. ${ }^{107}$ Somali pirates do not generally engage in belligerent acts with government forces. Instead, they use violence against civilian ships at sea. Additionally, pirate-fighters do not fit the traditional NIAC narrative of insurgents seeking political change. They are in all likelihood motivated by private gain, although their true motivations are not entirely clear. While subjective motivations for violence are not strictly part of the AP II definition, in this case they form part of a narrative that is sometimes used to justify pirates' violent acts.

It is difficult to conclusively determine how much these unique distinctions cause trouble with fitting the case of shore-based pirate-fighter networks into the definition of NIAC under international law. I return to these unique characteristics later, but I first analyze how well other attributes of the potential conflict fit within the current law defining NIAC. Beyond AP II, international tribunals and subsequent treaties have created a more detailed framework to consider. ${ }^{108}$ The most widely cited case that expands on the definition of NIAC is from the International Criminal

103. It is also not clear whether organized groups of pirate-fighters would meet the AP II requirements of being "under responsible command ... and [being able] to implement [the] Protocol." AP II, supra note 100, art. 1. This is addressed further in Part II.A.1.a.2 infra. See also PARTNERSHIP \& ACTION PLAN, supra note 20.

104. AP II, supra note 100.

105. See IMO Piracy Report, supra note 4.

106. See Singh, supra note 7.

107. See AP II, supra note 11, art. 1(1) (stating that the Protocol applies "between [the state's] armed forces and dissident armed forces or other organized armed groups"). This treaty-based definition has since been expanded by international criminal tribunals to include fighting between organized armed groups. See Prosecutor v. Tadic, Case No. IT-94-1-AR72, Decision on Defence Motion for Interlocutory Appeal on Jurisdiction, 970 (Int'1 Crim. Trib. for the Former Yugoslavia Oct. $2,1995)$ (" $[\mathrm{W}] \mathrm{e}$ find that an armed conflict exists whenever there is a resort to armed force between States or protracted armed violence between governmental authorities and organized armed groups or between such groups within a State.").

108. See Karl Josef Partsch, Armed Conflict, in 1 EnCYClopedia OF Public InTERnATIONAL LaW ๆ 26 (Rudolf Bernhardt, ed., 1992). 
Tribunal for Yugoslavia-Prosecutor v. Tadic. ${ }^{109}$ The case is noteworthy not only for its detailed analysis of the threshold of NIAC, but also for its broad acceptance. ${ }^{110}$ The Tadic decision on jurisdiction is widely considered to reflect customary international law, ${ }^{111}$ and parts of the holding were ultimately codified in Art. 8(2)(f) of the Rome Statute. ${ }^{112}$

\section{a. Tadic factors}

In Tadic, two factors were analyzed to determine whether a de facto armed conflict existed: the intensity of the hostilities, and the organization of the parties to the conflict. ${ }^{113}$ Each is addressed in turn.

\section{Intensity of the conflict}

The pirates' violent acts at sea and on shore likely satisfy the "intensity of the hostilities" threshold that the Court articulated in Tadic. ${ }^{114}$ In evaluating the level of hostilities, the Court focused "on the protracted nature of the conflict vice $[$ sic $]$ the magnitude of the attacks." ${ }^{115}$ But even the magnitude of the pirates' protracted hostilities is significant. A recent U.N. report noted that "[i]n 2011, using better and heavier weapons, pirates have targeted more oil tankers and sailing vessels. Violence against seafarers has also increased." 116 The type of weapon used is one indicator

109. Prosecutor v. Tadic, Case No. IT-94-1-A, Appeals Chamber Judgment, ๑ף 163-70 (Int'l Crim. Trib. for the Former Yugoslavia July 15, 1999); see also Cullen, supra note 99, at 98 ("[Tadic] considerably influenced the development of international humanitarian law.").

110. Tadic, Appeals Chamber Judgment, ๆף 163-70; Cullen, supra note 99, at 98.

111. See Ian Corey, The Fine Line Between Policy and Custom: Prosecutor v. Tadic and the Customary International Law of Internal Armed Conflict, 166 MIL. L. REV. 145, 155 (2000) ("the [Tadic] court seemed to conclude that such pronouncements evidenced both practice and opinio juris by implication.").

112. See Anthony Cullen, The Parameters of Internal Armed Conflict in International Humanitarian Law, 12 U. MiAMI INT'L \& COMP. L. REV. 189, 206 (2004) ("The Tadic formula for the recognition of internal armed conflict is included, albeit slightly amended, in the Rome Statute of the International Criminal Court."). By its inclusion, it ultimately governs whether a NIAC exists for the purpose of determining liability for war crimes.

113. See Prosecutor v. Tadic, Case No. IT-94-1-AR72, Decision on Defence Motion for Interlocutory Appeal on Jurisdiction, 70 (Int'l Crim. Trib. for the Former Yugoslavia Oct. 2, 1995).

114. This section looks only at the "absolute value" of hostilities and sets aside the issue that the hostilities are addressed in the "axis" between the pirates and ships at sea (versus between the pirates and government forces or possibly another armed group). This anomaly is addressed separately.

115. ANTHONY CULlEN, THE CONCEPT OF NON-INTERNATIONAL ARMED CONFLICT IN INTERNATIONAL HUMANITARIAN LAW 127 (2010) ("It is clear that the intensity required for the existence of armed conflict is above that of internal disturbances and tensions. It is also clear that hostilities need not reach the magnitude of 'sustained and concerned military operations.' The issue is one of clarifying the threshold of intensity that is required for the characterization of a situation as one of armed conflict. This degree of intensity hinges on the interpretation of the word 'protracted."').

116. Res. 1950 Report, supra note 5, 99. 
of whether an armed conflict exists. ${ }^{117}$ In this case, the weapons used by pirates rise to the level of crew-served weapons, and have inflicted damage on naval warships. ${ }^{118}$

Focusing specifically on the "protracted nature of the conflict," organized pirate-fighters have controlled vast areas of the sea off the coast of Somalia for several years. In 2008, the Security Council first expressed grave concern over "the threat that acts of piracy and armed robbery against vessels pose to the prompt, safe and effective delivery of humanitarian aid to Somalia, the safety of commercial maritime routes and to international navigation," and deplored the "recent incidents of attacks upon and hijacking of vessels." 119 Since then, the Council has addressed the issue in terms of a threat to international peace and security twelve times. ${ }^{120}$ The scope of the authorized response has also progressed. ${ }^{121}$

Further, there is good reason that the current lull in the violence should not save pirate-fighters from a conclusion that hostilities are still protracted and ongoing. Bases, materials, and equipment still render them capable of escalating their attacks, and they still actively hold ships for ransom and keep captives ashore. ${ }^{122}$ The intensity of the hostilities could be seen as extending to the ruthless treatment of hostages and prisoners, and to the widespread practice of employing children in low-level pirate attacks. $^{123}$

Thus, the combination of sustained attacks at sea using military hardware and tactics since at least 2008, coupled with a robust and violent shore-based hostage network, makes the pirate conflict fall readily within the Tadic threshold for the intensity of the conflict.

\section{Organization of the parties}

The difficulty in gathering reliable open-source data regarding pirate network operations makes it ultimately unclear whether pirates would meet the substantive requirements of an "organized armed group," which is the second threshold question for a NIAC under Tadic. ${ }^{124}$ According to U.N.

117. See Prosecutor v. Haradinij, Case No. IT-04-84-T, Judgment, ๆף 49, 60 (Int’l Crim. Trib. for the Former Yugoslavia Apr. 3, 2008).

118. See Suspected Pirates Nabbed After Skirmish with U.S. Navy Ship, CNN (Apr. 1, 2010), http://www.cnn.com/2010/WORLD/africa/04/01/navy.pirates/index.html.

119. See supra note 35 .

120. Id.

121. See S.C. Res. 1851, supra note 9, \2; S.C. Res. 2077, supra note 35, \10.

122. See Singh, supra note 7.

123. Res. 1950 Report, supra note 5, $₫ 35$.

124. See Prosecutor v. Tadic, Case No. IT-94-1-AR72, Decision on Defence Motion for Interlocutory Appeal on Jurisdiction, 970 (Int'l Crim. Trib. for the Former Yugoslavia Oct. 2, 1995). 
reports, pirate clans fall under responsible commands in a hierarchical structure, although it is not clear how much coordination is done between various clans. ${ }^{125}$ Clans of pirates "exud[e] cold ruthlessness and demonstrat[e] a proclivity for torture and violence." "126 Pirate leaders have even given statements to the press from their lawless enclaves, in one case claiming that they cannot be stopped. ${ }^{127}$ In the context of prosecutions, the U.S. has claimed the need to target the "upper tiers of the pirate hierarchy," and demonstrate "that individuals beyond the gunmen in skiffs are culpable...."128 Their organization is further underscored by their development of a piracy "stock exchange." 129

Furthermore, pirate clans operate from discrete bases along the coast of Somalia, and operate in designated areas both on land and at sea. Armed pirate groups exercise de facto control over their territory. ${ }^{130}$ Indeed, this control is what has allowed them to function outside the law in the first place.

Thus, although a lack of reliable information impedes a clear conclusion, significant indicators exist that the pirates' level of organization meets the threshold contemplated in Tadic. U.N. member states undertaking such analyses, furthermore, would likely have greater means at their disposal, including discrete intelligence collection, to make a more specific and credible determination.

\section{Challenges to applying the Tadic framework}

The Tadic decision is commonly viewed as having expanded the number of conflicts considered to be a NIAC, as compared with the definition in AP II. ${ }^{131}$ While it certainly seems to offer a more holistic

125. See Joshua Hammer, Tracking Somali Pirates to Their Lair, N.Y.TIMES, Aug. 5, 2011, http://www.nytimes.com/2011/08/07/books/review/the-pirates-of-somalia-by-jay-bahadur-bookreview.html ("The organizational structure of typical pirate cells... includes not just attackers, interpreters, accountants and cooks: almost every group also has its supplier of khat,... high or low, these brigands practice some peculiar rituals. After receiving his cut of the ransom on the captured ship, one pirate tells Bahadur, each man must toss his mobile phone into the ocean-a precaution to make sure no one can call ahead to his kin to arrange an ambush of his fellow cell members.").

126. Id. (internal quotation marks omitted).

127. See David McKenzie, No way to stop us, pirate leader says, CNN (Dec. 4, 2008), http://articles.cnn.com/2008-12-01/world/pirate.interview_1_international-maritime-bureau-somalicoast-pirate-attacks.

128. See Andrew J. Shapiro, Turning the Tide on Somali Piracy, Remarks to the Atlantic Council (Oct. 26, 2012).

129. See Sterling, supra note 22.

130. Res. 1950 Report, supra note 5, I 14 ("Recently, 'Galmudug' has become one of the most prolific pirate bases. The 'Galmudug' counter-piracy task force has expressed its intention to develop a maritime police unit both on and off shore.”).

131. Cullen, supra note 99, at 108-09. 
framework for analysis, it still doesn't lead to a firm conclusion that the use of force under Resolution 1851 against Somali pirate-fighters would rise to that level. The two problems first introduced above-the direction of hostilities to sea (versus toward the government), and the motive for private gain-still present unique concerns with labeling it "armed conflict." While it is ultimately unclear how these two additional nuances would change the analysis under Tadic, there is a strong case to be made that they should not disrupt an otherwise reasonable conclusion that the scenario constitutes a NIAC.

Although pirates target civilian ships at sea instead of government forces, there are two reasons that this should not save them from being considered capable of engaging in a NIAC if other required criteria are satisfied. First, the pirates' hostilities must be viewed in the context of their base of operations: Somalia, a country of widespread and relative (though recently improving) lawlessness. ${ }^{132}$ The presence of armed pirate fighters presents a hostile threat to the government's authority, even though they may not be actively fighting government troops. The complexity of organized pirate operations strongly suggests that they operate with impunity in the areas they control. ${ }^{133}$ They have used bases on land (as well as vessels docked directly offshore) to hold dozens of hostages in inhumane conditions. ${ }^{134}$ Thus, hostilities between the pirates and government forces can be considered "latent." Their organization and control presents a hostile threat to the government's authority and the rule of law. The government is unable to respond, but if it were to engage in hostilities with the armed pirate clans, those activities would likely be considered NIAC. Therefore, U.N. member states should be seen as stepping into the government's role (and a potential NIAC) when carrying out the Security Council's decision in Resolution 1851 and using force consistent with the Somali government's request.

Second, international tribunals have not held that participation by government forces is required, AP II notwithstanding. ${ }^{135}$ In Tadic, the Court was confronted with a determination of whether a novel situation was included in the definition of armed conflict, one in which "no government party is involved because two or more non-state entities are

132. See UN experts on use of mercenaries urge greater oversight for private security contractors, UNITED NATIONS NEWS CENTER REPORT (Dec. 18, 2012), http://www.un.org/apps/news/story.asp ?NewsID=43797\#.UYHCDbWR98E.

133. See PlOCH ET AL., supra note 8, at 10-11.

134. See Kaija Hurlburt et al., The Human Cost of Somali Piracy Report, 7-8 (2012).

135. AP II, supra note 100, art. 1(1). 
fighting each other."136 The Court signaled that the involvement of a government actor was not a necessary criterion for a NIAC as long as the organization of the parties and level of the hostilities were sufficient to meet the required thresholds. It would follow, then, that if, hypothetically, the civilian ships attacked by pirates fought back (thereby reciprocating hostilities), the scenario would more closely approach the criteria for NIAC. ${ }^{137}$ The attacking of defenseless civilian vessels - which are never considered lawful targets of attack - instead of another fighting force should not save pirates from being considered as involved in a NIAC if other relevant criteria are satisfied. The pirate-fighters' unlawful holding of civilian prisoners and attacks on civilian targets could be seen as types of "war crimes" that, on account of their magnitude, should be considered in the analysis. In evaluating a traditional "rebel-on-state" NIAC, the "intensity of the hostilities" would likely consider the magnitude of any unlawful acts of violence, in addition to the hostilities engaging state forces. ${ }^{138}$ It seems unusual that the potential war crimes of pirate-fighters (that is, the targeting innocent civilians) would not be considered in the magnitude of hostilities simply because they also happen to be crimes of universal jurisdiction under international law.

While pirates' primary aim is commonly accepted to be financial gain, their purported lack of political motivation should not render them incapable of engaging in NIAC. ${ }^{139}$ There are two reasons for this. First, it has no foundation in IHL. ${ }^{140}$ Second, it is contrary to at least some pirates' claimed justification for their actions. ${ }^{141}$

Neither AP II nor the Tadic definitions, nor any other instrument of

136. See CULLEN, supra note 115 , at 119.

137. This limited hypothetical is for illustration purposes only. Any involvement in hostilities on the part of pirated vessels would need to be organized in order to rise to the level of a NIAC, and it would present the additional complication of shifting the dynamic to one vis-à-vis the pirate-fighters and their victim ships, versus the relevant dynamic of pirate-fighters vis-à-vis the Somali government combined with other states enforcing relevant U.N. Security Council Resolutions.

138. See also Prosecutor v. Mrkšić, et al., Case No. IT-95-13/1-T, Judgment, ๆ 407 (Int'l Crim. Trib. for the Former Yugoslavia Sept. 27, 2007) ("[factors for evaluating the intensity of the conflict include] the seriousness of attacks and potential increase in armed clashes, their spread over territory and over a period of time, the increase in the number of government forces, the mobilisation and the distribution of weapons among both parties to the conflict, as well as whether the conflict has attracted the attention of the United Nations Security Council, and if so whether any resolutions on the matter have been passed.").

139. The overlap with liability under criminal law for pirates' actions is addressed further, infra.

140. See Sylvain Vité, Typology of armed conflicts in international humanitarian law: legal concepts and actual situations, 91 INT'L REV. OF THE RED CROSS 69, 78 (Mar. 2009).

141. See Rep. of the Special Adviser to the Secretary-General on Legal Issues Related to Piracy off the Coast of Somalia, ๆ 90, U.N. Doc. S/2011/30 (Jan. 25, 2011) (Jack Lang) [hereinafter Lang Report]. 
IHL, speaks to the subjective motive of an "other organized group" for espousing violence. ${ }^{142}$ Nonetheless, pirates are sometimes given a reflexive "pass" because their goals are perceived to be mere subsistence in admittedly one of the most challenging domestic economies in the world. ${ }^{143}$ Some commentators have even justified pirates' violence. ${ }^{144}$ But focusing solely on the pirates' supposed profit motive is contrary to some pirates' claimed intent. Adopting a model pirates themselves have advocated, they do, in fact, have political objectives - to protect the Somali coast and eliminate foreign influence, including dumping. ${ }^{145}$ Ironically, giving pirates the status that they themselves seem to desire makes them more likely to be considered an organized fighting force with a common mission and the desire to employ hostilities to achieve it. ${ }^{146}$ This seems to push them closer to the customary international law definition of NIAC as reflected in Tadic.

Thus, concerns that the pirates' motives or chosen victims make the existence of a NIAC less likely would be largely misplaced. ${ }^{147}$ These two challenges can be accommodated by the AP II definition amplified by the Tadic framework. Broader implications of this possible gap in the NIAC framework are explored next.

b. Problems presented by the pirate-fighter case to the definition of NIAC

Those who have analyzed the case of Somali piracy have all concluded that a NIAC does not currently exist. ${ }^{148}$ The question, however,

142. See CULLEN, supra note 115 , at 130-31.

143. See, e.g., Guilfoyle, supra note 43, at 6 (implying an analogy with displaced persons who "cross a land border and begin hijacking trucks, to make a living following the destruction of their farm lands. In such a case we would not seriously contend that such displaced persons were in any sense acting as belligerents.").

144. Nicole Stillwell, Robbers or Robinhoods?: A Study of the Somali Piracy Crisis and A Call to Develop an International Framework to Combat Maritime Terrorism, 7 LOY. MAR. L.J. 127, 134-35 (2009) ("These detainees are being charged with piracy, although not all Somali attacks are piracy per se. Somalis do not always act for private ends. Somalis act to defend their coasts and support their communities. Additionally, their attacks are not only on the high seas, but also in their coastal waters and exclusive economic zones. They are supported by local government and their community. Finally, their attacks originated as a means to provide support and protection in the absence of government. Thus, the incidents in Somalia do not resemble piracy pursuant to the definitions under UNCLOS.").

145. See, e.g., Lang Report, supra note 141, ๆๆ 12-13.

146. However, pirates could never be a legitimate Coast Guard because their violence is not sanctioned by the sovereign - in this case, Somalia.

147. See Stillwell, supra note 144.

148. See Guilfoyle, supra note 43, at 3-7; see also Treves, supra note 32, at 412 ("This is not use of force against the enemy according to the law of armed conflict, because there is no armed conflict, international or internal. Pirates are not at war with the states whose flotillas protect merchant vessels in 
does not yet seem to have been framed as one encompassing the whole of organized pirate-fighter activity-both on shore and at sea. ${ }^{149}$ Most attempted applications of the threshold criteria for a NIAC have centered on the pirates' actions at sea only. ${ }^{150}$ When the Tadic factors analyzed above are fully considered, however, the actions of organized piratefighters ashore provide the most thorough and consistent support for the notion that a NIAC could be found in Somalia between states enforcing Resolution 1851 and these pirate-fighter groups. This section addresses other possible objections to applying the NIAC framework to the whole of organized pirate activity, including the overlap with criminal law and the challenges U.N. member states face when making determinations about what law applies to their actions ashore in Somalia.

\section{Law enforcement overlap}

To be clear, I do not claim that the international law of piracy contained in the U.N. Convention on the Law of the Sea (UNCLOS) does not apply. ${ }^{151}$ There is no reason that the international crime of piracy at sea could not occur in conjunction with, as well as independent of, a possible NIAC. Just as those engaged in a more familiar civil war-type NIAC may be liable criminally for violations committed incidental to that conflict, so too are those parts of the pirate-fighter network that launch sea-based attacks. While the attacks against merchant ships are certainly crimes of universal jurisdiction under international law, ${ }^{152}$ they might also be launched with military-style weapons using a highly organized force operating in networks thousands of miles from shore. The issue of whether such acts are part of a much larger NIAC is a separate question from the issue of criminal liability for any particular act of piracy.

2. State practice and the challenge of recognition

The notion that any type of armed conflict exists with pirate-fighters ashore is likely controversial. The difficulty of determining whether a NIAC exists, especially at the lower end of the spectrum, has been

the waters off the coast of Somalia .... Whatever opinion one holds about the applicability of the law of armed conflict, it is a fact that practice in the waters off Somalia seems to indicate that warships patrolling these waters resort to the use of weapons only in response to the use of weapons against them." (emphasis added)); Sterio, supra note 70. Finally, the Lang Report, supra note 141, makes no mention of armed conflict.

149. Guilfoyle, supra note 43 , at 3-7.

150. Id.

151. UNCLOS, supra note 15 , arts. 100-105.

152. See J. Ashley Roach, Countering Piracy Off Somalia: International Law and International Institutions, 104 AM. J. INT’L L. 397, 398 (2010). 
recognized. In the Tablada case, the Inter-American Commission on Human Rights found that:

[t]he most difficult problem regarding the application of Common Article 3 is not at the upper end of the spectrum of domestic violence, but rather at the lower end. The line separating an especially violent situation of internal disturbances from the "lowest" level Article 3 armed conflict may sometimes be blurred and, thus, not easily determined. When faced with making such a determination, what is required in the final analysis is a good faith and objective analysis of the facts in each particular case.

Even though the Security Council has not, as of yet, noted that this particular situation in Somalia rises to the level of a NIAC, a "good faith and objective analysis of the facts," as the Tablada Court suggested, might lead some states to conclude that a NIAC exists between at least some organized pirate-fighters, on one side, and the Somali government (supported by states enforcing Resolution 1851) on the other. ${ }^{154}$ As tribunals have noted, the standard is difficult to apply. ${ }^{155}$ Because the decision of the Security Council was unclear, ${ }^{156}$ it falls to states that carry out the Council's decision to undertake the analysis. ${ }^{157}$ Prospectively, states necessarily engage in an independent analysis of the existence of a NIAC - a law-triggering decision - when deciding how they might give effect to the Security Council's mandate. One could envision individual states giving more or less weight to the Council's invocation of "applicable IHL." 158

Presently, however, no state has publicly concluded that the situation has risen to a NIAC. ${ }^{159}$ As a hypothetical, suppose that organized groups

153. Juan Carlos Abella v. Argentina, Case 11.137, Inter-Am. Comm'n H.R., Report No. 55/97, OEA/Ser.L/V/II.95, doc. 7 rev. 153 (1997) [hereinafter Tablada].

154. None of the applicable Security Council Resolutions currently recognizes a NIAC in Somalia involving armed pirate groups. The International Committee of the Red Cross, while recognizing the existence of a NIAC in Somalia between the government and the Al Shabaab militia, recognizes no such state of conflict vis-à-vis armed pirates. As of this writing, no states have publicly expressed that IHL applies to the use of force against armed pirates, and it is unclear if EUNAVFOR made that affirmative conclusion prior to the May 2012 use of force. To be clear, there might be situations in which IHL is determined to apply without concluding that a NIAC exists. These are explored further below.

155. See Tablada, supra note 153, ๆ 153.

156. See introduction to Section II, supra.

157. This is not to suggest that any such determination would be made capriciously. Such conclusions are always subject to domestic and international political review, judgment, and possible criticism and revision. Mechanisms are in place to correct clearly erroneous conclusions, including review by the Security Council under Chapter VII. See U.N. Charter, supra note 76, arts. 39-42.

158. S.C. Res. 1851, supra note 9 , $\mid 6$.

159. According to the author's research as of December 31, 2013. See also supra note 154. 
of armed pirates operated from an expansive physical headquarters on the coast, and employed a rigid hierarchical chain of command, including "Pirate Admirals" and "Flotilla Commodores" that directed the actions of individual ships in seeking out civilian "victim vessels" at sea. Several smaller "pirate stations" dock ships and house logistics depots whose local commanders report directly to the high pirate headquarters.

In this hypothetical, the headquarters formulates strategy. Their initial success means that their strategy must evolve over time in response to the targets' changing tactics. Leaders at headquarters direct subordinate bases to launch individual attacks, but don't micromanage details, which are left to individual captains and lieutenants. Once a transiting merchant is located by a ship in this pirate forces network, the victim vessel would be subject to an attack with grenade launchers and machine gun fire. The specific tactics used would be modified in accordance with headquarters' most recent strategic guidance. The attack would be enough to implore the vessel to stop, but not to sink it or significantly damage its cargo. Small boats of soldier-sailors under the command of the pirate ship's master would take over the ship, commandeer it, and take all crewmembers hostage.

Once taken hostage, captives would be sent back to shore via the same highly-developed network. At that point, other officers in the rigid hierarchy would kick into gear, immediately starting the negotiation process to demand ransom for the vessel. Separate financiers could trade shares of the vessel being held, thus laying claim to future ransom payouts while at the same time funding more current operations. Local citizens far and wide know that their government's forces are powerless to stop the armed pirates. In fact, the government doesn't even attempt to do so. (All of their limited resources are engaged in fighting a separate resistance movement.) Local police efforts to subdue and overtake the headquarters would be futile given the significant cache of military hardware that protects it. By extension, the local and national authorities are powerless to stop the increasingly ruthless and violent attacks perpetrated by the pirates at sea, yet based, directed, and networked from their headquarters ashore.

In this hypothetical, the Tadic factors - organization of the parties and the level of hostilities - start to approach a theoretical extreme. It becomes difficult to argue that a regime of NIAC should not apply to the pirates' organized and coordinated violent acts. ${ }^{160}$ As stated above, though, in

160. The situation can even start to be seen as one of hostilities with the sovereign state, except that the sovereign state is powerless to initiate the use of force. In this sense, the "level of hostilities" prong should allow for the possibility of "latent hostilities"- situations in which the lawless group is so powerful and the state so relatively weak that the unlawful group should not be saved from being 
reality it is individual states that make independent assessments of the existence (or lack thereof) of a NIAC based on the facts, subject to review and possibly clearer guidance by the Security Council. A determination that there is a NIAC allows for the application of IHL, which reflects the reality of the required response in the above hypothetical.

One possible conclusion states might consider is that IHL would apply to the use of force ashore in Somalia even if the threshold for NIAC is not reached. This idea, which possibly underscored the EU's constraints and targeting decisions when it used force ashore in May 2012, is explored further below. But first, I look at how the substantive principles of IHL might be applied to the Council's mandate for use of force against pirates.

2. If there is a NIAC, how would IHL be applied?

The substantive IHL applicable during NIAC is set forth in various sources, most specifically in AP II. ${ }^{161}$ As discussed above, AP II expands on Common Article 3 to the Geneva Conventions, which bestowed certain minimum obligations on the parties. ${ }^{162}$ Additionally, the customary IHL applicable during NIAC would apply to the conduct of hostilities. ${ }^{163}$ This section broadly analyzes these principles specific to the application of force - the most relevant subset of IHL here because they are needed to give effect to the Council's mandate.

\section{a. Destruction of pirates' materiel}

The most fundamental customary principles of IHL-necessity, proportionality, and discrimination-would apply to the use of force in Somalia against pirates' "boats, vessels, arms and other related

considered engaged in a NIAC because of their ruthlessly violent, but possibly private ends. This would also approach the requirement in Tadic that an armed conflict requires "protracted armed violence between governmental authorities and organized armed groups or between such groups within a state." See Prosecutor v. Tadic, Case No. IT-94-1-AR72, Decision on Defence Motion for Interlocutory Appeal on Jurisdiction, 70 (Int'l Crim. Trib. for the Former Yugoslavia Oct. 2, 1995).

161. See AP II, supra note 100, arts. 4-18.

162. Scholars have disagreed about the applicability of AP II in situations where a foreign power intervenes on behalf of government forces. In the context of the situation in Mali, scholars have noted that, "[a] broader interpretation - one that, in the view of the present authors, better fits with the language employed, as well as with basic logic - is that the Protocol applies to each and every party to any armed conflict that meets the criteria of Article 1(1)." Rogier Bartels, The French intervention in Mali and Additional Protocol II, ARMed Groups AND InTERnAtional LaW Blog (Jan. 17, 2013), http://armedgroups-internationallaw.org/2013/01/17/the-french-intervention-in-mali-and-additionalprotocol-ii/.

163. See Jean-Marie Henckaerts, Study on Customary International Humanitarian Law: A Contribution to the Understanding and Respect for the Rule of Law in Armed Conflict, 87 INT'L REV. OF THE RED CROSS 175 (2005). 
equipment."164 This pirate materiel could be destroyed much as any military target could be designated in an armed conflict scenario, with strict adherence to fundamental principles of IHL.

First, the principle of necessity would govern the selection of targets. ${ }^{165}$ Military necessity has historically been considered an expansive concept that prohibited only attacks that led to no concrete military advantage. ${ }^{166}$ In the case of using force on land to suppress piracy at sea, however, "military advantage" could be defined more narrowly to give precise effect to the Council's mandate. Anything used in the course of piratical attacks could be destroyed, but if a vessel, vehicle, or other piece of equipment is not directly enabling piracy, attacking it might be disallowed. Thus, "military necessity" would be derived from the Council's decision to use "all necessary measures" to suppress piracy. ${ }^{167}$

Second, the principle of distinction requires that civilians and civilian objects be differentiated from lawful military targets. ${ }^{168}$ As applied here, states would be required to ensure that civilian residences, fishermens' boats and equipment, and other objects with no direct connection to piracy are not targeted.

Finally, proportionality is likely the most difficult principle to apply in practice. The concrete advantage to be gained from the use of force must not be disproportionate to the expected civilian collateral damage. ${ }^{169}$ Proportionality recognizes that some collateral damage is inevitable under the doctrine of dual effect. ${ }^{170}$ It is unclear what would constitute acceptable collateral damage in the piracy context. According to one Council member, the possibility of collateral damage was known and therefore likely considered, but the Resolution passed anyway. ${ }^{171}$ The lowest possible thresholds would likely need to be applied so that the intent of the Council is met.

164. See AP II, supra note 100, arts. 4, 13; S.C. Res. 1851, supra note 9, at 2 .

165. See, e.g., Jean-Marie Henckaerts \& Louise Doswald-Beck, Customary International Humanitarian Law-Volume I: Rules, INT'L COMM. OF THE RED CROSS 175 (2005), available at https://www.icrc.org/eng/assets/files/other/customary-international-humanitarian-law-i-icrc-eng.pdf ("The destruction or seizure of the property of an adversary is prohibited, unless required by imperative military necessity.").

166. See Michael N. Schmitt, Fault Lines in the Attack, in TeSTING THE BOUNDARIES OF INTERNATIONAL HUMANITARIAN LAW 277, 277 (Susan Breau \& Agnieszka Jachec-Neale eds., 2006).

167. S.C. Res. 1851, supra note 9, at 96.

168. See Henckaerts \& Doswald-Beck, supra note 165, at 25-34.

169. See id. at 46 .

170. See DRURY, supra note 61, at 67-68.

171. Press Release SC/9541, supra note 53. Dumisani Kumalo of South Africa "expressed concern over the provision in the resolution that allowed for States to conduct land-based operations against piracy, saying there was a danger that innocent Somalis could fall victim to those operations." Id. 
b. Possible targeting of pirate fighters

Any determination under IHL that would support targeting suspected pirate-fighters themselves would be much more difficult. By default, pirates are criminals and not combatants. ${ }^{172}$ Under several plausible circumstances, however, they could be lawfully subjected to force.

To be subjected to targeting simply because of their status as parties to a NIAC, individual pirates must first be positively identified as members of the organized armed pirate group taking part in the conflict. ${ }^{173}$ Piratefighters would constitute an "organized armed group" subject to targeting because of their status alone. ${ }^{174}$ Even so, there are challenges to making a conclusive determination about an individual's status when they themselves don't follow relevant IHL provisions regarding identifying themselves as parties to the conflict. ${ }^{175}$ Because of these challenges, it is conceivable that perhaps only very few individuals would qualify based on the information required for pirate fighters to be targetable simply because of their status.

If not positively identified as a pirate-fighter, an individual (by default a protected civilian under IHL) could also take some action that causes them to lose their protected status, thus making them targetable. This determination that the individual is directly "participating in the hostilities" would require a specific determination to be made prior to such targeting. Individuals would be targetable only "for such time as they take a direct part in hostilities."176

Both of these analyses would be difficult to execute in practice. When not armed and readying for attack at sea or guarding hostages, Somali pirates are likely to be generally indistinguishable from fishermen, and might be in close proximity to other non-combatants during engagements that would likely take place at significant ranges. ${ }^{177} \mathrm{~A}$ rigorous

172. See Kontorovich, supra note 11 .

173. Id. See International Institute of Humanitarian Law, The Manual on the Law of Non-International ARmed CONFLict With COMMENTARy 4 (2006). The term "combatant" is unique to IAC. The term "fighter" has been used to describe individuals who engage in NIAC, but the term does not appear in any binding treaty.

174. For a discussion of the challenges surrounding targeting individuals in NIAC, see Marco Sassoli \& Laura Olson, The Relationship Between International Humanitarian and Human Rights Law Where it Matters: Admissible Killing and Internment of Fighters in Non-international Armed Conflicts, 90 INT'L REV. OF THE RED CROSS 599, 606-07 (2008).

175. AP II, supra note 100, art. 1

176. AP II, supra note 100, art. 13, 9 3; see also Jamie A. Williamson, Challenges of Twenty-First Century Conflicts: A Look at Direct Participation in Hostilities, 20 DUKE J. CoMP. \& INT'L L. 457, 471 (2010).

177. Proportionality concerns would also need to be addressed. 
intelligence-based analysis and thoroughly vetted status- and conductbased rules of engagement (ROE) would be necessary to ensure strict adherence to IHL, should the NIAC framework be found to apply. During a NIAC, though, such targeting would be permissible if done according to the principles of IHL discussed above. Of note, the targeting of piratefighters is not specifically prohibited by the text of the Resolution, and the "all necessary measures" language is fundamentally permissive.

There is no evidence the Security Council even considered the question of specifically targeting individuals. ${ }^{178}$ The means presented here by which pirates could be targeted are largely jus in bello restrictions. There could also be a jus ad bellum restriction on targeting suspected Somali pirates. That is, the pirates themselves possibly don't fall within the scope of the authorization to use force under Resolution 1861. The Resolution authorizes "all necessary measures... appropriate in Somalia."179 Perhaps targeting individual pirates is not necessary to pursue the Council's objectives. Or, perhaps the Somali government would not consider it appropriate. Though IHL might be found to apply to the conflict, these restrictions could otherwise limit the means by which the states aligned with the Security Council and Somalia could carry out that mandate for political reasons. Under a functional approach, these limits would be legally unobjectionable. ${ }^{180}$

In any case, the Security Council's intent to use force in Somalia to suppress piracy might be effectively executed without targeting individual pirate-fighters. A further analysis of this question is beyond the scope of this Article, but given the humanitarian situation in Somalia it is perhaps even preferable. The restrictions discussed in this section are only those arising under international law. Other concerns, including policy and domestic law, may cause participating states to put more robust restraints on the use of force in this context. Applying IHL is possible without declaring pirate-fighters to be targetable per se.

Finally, whether or not IHL applied, if an individual pirate or group of pirates were to launch an attack or threaten imminent attack on forces carrying out Resolution 1851, the use of necessary and proportional force

178. See, e.g., S.C. Res. 1851, supra note 9; Press Release SC/9541, supra note 53.

179. S.C. Res. 1851, supra note 9.

180. A full examination of possible conflation issues here is beyond the scope of this analysis. See generally Robert D. Sloane, The Cost of Conflation: Preserving the Dualism of Jus Ad Bellum and Jus in Bello in the Contemporary Law of War, 34 YALE J. INT'L L. 47, 102-03 (2009) (“[M]odernity has witnessed an erosion of the dualistic axiom. In part, this reflects the practical pressures brought to bear on the law of war by advances in technology, geopolitical reconfiguration following the Cold War, and evolution in the nature of war itself."). 
in self-defense would be justified. ${ }^{181}$

B. If the conflict falls short of a NIAC, could IHL still apply?

A finding that a NIAC is underway between pirate-fighters and states enforcing Resolution 1851 might not be a necessary condition to the applicability of IHL. Many commentators have recently advanced the idea that IHL has at least limited applicability to "gray zone" conflicts such as this, ${ }^{182}$ and commentators have acknowledged that there is not a full definition of those situations that fall within the material field of application of IHL. ${ }^{183}$ Additionally, there might be circumstances under which the conflict with organized pirate-fighters could be associated with the ongoing conflict between Somali government forces, Al Shabaab, and associated militias. ${ }^{184}$ Under these two possible scenarios, IHL might be applied to a situation that does not rise to the level of a discrete NIAC.

\section{Applicability of IHL to "gray zone" conflicts}

The authorized "necessary measures" - that is, force-most recently taken by the EU necessarily must have been carried out according to IHL. While Resolution 1851 provides the jus ad bellum that justifies the use of force in Somalia to suppress piracy, there must also be an applicable jus in bello.

"[A]pplicable IHL" was specifically cited in Resolution 1851 in the same sentence that ultimately authorized force. ${ }^{185}$ Commentators have raised the question of whether the Security Council is competent to declare IHL applicable to its decisions to authorize force that don't amount to armed conflict. In analyzing the Council's authorization for force in Haiti in 2004, Professor Siobhán Wills raised the question: "[C]an the Security Council implicitly authorise use of IHL instead of [international human rights law] in situations where there is no armed conflict (in contradiction to the terms of the UN's own Bulletin on the matter) merely by stating that it is 'acting under Chapter VII'?"186

181. U.N. Charter, supra note 76, art. 51; See also Kontorovich, supra note 11.

182. See Sven Peterke, Regulating "Drugs Wars" and Other Gray Zone Conflicts: Formal and Functional Approaches, HuMANITARIAN ACTION IN SITUATIONS OTHER THAN WAR (HASOW), DISCUSSION PAPER 1, 2 (2012), available at http://hpcrresearch.org/sites/default/files/publications/

Svens\%20Paper.pdf.

183. See Vité, supra note 140 , at 70.

184. See GeISS \& PETRIG, supra note 12, at 132.

185. S.C. Res. 1851, supra note 9, ๆ 6.

186. Siobhan Wills, The Law Applicable to Peacekeepers Deployed in Situations Where There is No Armed Conflict, BLOG OF THE EUR. J. OF INT'L L. (Apr. 10, 2013), http://www.ejiltalk.org/the-lawapplicable-to-peacekeepers-deployed-in-situations-where-there-is-no-armed-conflict/. 
The issue has generated significant debate. On one hand, the U.N. Security Council has "primary responsibility for the maintenance of international peace and security" and should be competent to decide that customary IHL applies to the use of force it specifically authorized. ${ }^{187}$ The Council's broad authority under the U.N. Charter strongly suggests the power to determine the applicability of customary IHL to the uses of force they specifically authorized "to restore international peace and security." The U.N. Security Council is specifically competent to make "calls for the respect of international humanitarian law." 189

On the other hand, some scholars have dismissed the mention of "applicable IHL" as merely referring to the law that would otherwise apply, and thus have given no practical legal effect to the Council's calls for additional force on land in Somalia. ${ }^{190}$ The Security Council, however, chose to include a reference to IHL. As shown in Part I, it also authorized force. Thus, it is logical to apply the Security Council's power to declare IHL applicable to its desired means for the purpose of reaching its desired end state, rather than to dismiss it as an irrelevant "savings clause."191 A more persuasive interpretation might be that the "applicable IHL" is meant to refer to at least the general principles of customary IHL-military necessity, proportionality, discrimination, and humanity - without which the Council's decision could not be given full effect. Additionally, the nature of the force authorized suggests that if customary principles of IHL did not apply, then no law (or perhaps inadequate or insufficient law) might be found to apply. ${ }^{192}$

Some scholars have argued that a functional or "problem-oriented" approach to the application of IHL is more appropriate than a legalistic method of determining the existence of NIAC. ${ }^{193}$ In analogous situations, some states have applied customary IHL to avoid this legal void, sometimes in conjunction with applicable human rights law. In the context of illegal narcotics, for example, "certain governments have declared

187. U.N. Charter, art. 24, 39-42, 103; see also Christiane Bourloyannis, The Security Council of the United Nations and the Implementation of International Humanitarian Law, 20 DENV. J. INT'L L. \& POL'Y 335, 342 (1992).

188. U.N. Charter, supra note 77, art. 39-42.

189. See Bourloyannis, supra note 187.

190. See GeISs \& PETRIG, supra note 11, at 131-35; Guilfoyle, supra note 43, at 6-7 (explaining that the mention of applicable IHL appears to be a "savings clause included out of the abundance of caution.").

191. Guilfoyle, supra note 43, at 7 .

192. S.C. Res. 1851, supra note 9 , at 92 .

193. See Peterke, supra note 182, at 16-17 (citing Daniel Thurer, INTERNATIONAL Humanitarian Law: Theory, Practice, Context (The Hague, Ail-Pocket 2011)). 
organized crime groups as the most serious threats to public order and pursued increasingly militarized actions against them." ${ }^{194}$ The use of paramilitarized police and armed troops in the struggle against organized crime groups has "raised questions about whether these situations have the potential to be classified as armed conflicts." 195

The potential application of IHL to "gray zone" conflicts even outside of Security Council sanction seems to add further weight to the argument that the Council is competent to decide the applicability of IHL under Chapter VII. Commentators have advocated a functional approach to applying IHL in gray zone conflicts. ${ }^{196}$ This approach has also been extended to targeting, which would allow IHL to function effectively to give effect to the Council's mandate while preserving humanitarian aims. ${ }^{197}$

\section{Association with the existing NIAC in Somalia}

Finally, there is one other entirely separate means by which armed pirate groups could possibly be considered to be engaged in a NIAC within Somalia. Because a separate Security Council Resolution already recognizes a separate armed confrontation occurring within Somalia, association of armed pirate groups with armed insurgents could effectively bring these pirates within the threshold of that NIAC. ${ }^{198}$ Analysts have suspected localized links between various pirate factions and other Somali insurgent groups, including Al Shabaab. ${ }^{199}$ Scholars have advocated for considering pirates as terrorists, at least in certain circumstances, and have drawn considerable parallels between today's terrorists and pirates. ${ }^{200}$ At

194. Id. at 2 .

195. See Robert Muggah, Part 1: Rethinking the Intensity and Organization of Violence in Latin America and the Caribbean, REINVENTING PEACE (Feb. 16, 2012), http://sites.tufts.edu/reinventing peace/2012/02/16/part-i-rethinking-the-intensity-and-organization-of-violence-in-latin-america-and-thecaribbean/.

196. See Peterke, supra note 182; see also Monica Hakimi, A Functional Approach to Targeting and Detention, 110 MicH. L. REV. 1365, 1391-96 (2012).

197. Hakimi, supra note 196.

198. See S. C. Res. 1872, ๆ 5, U.N. Doc. S/RES/1872 (May 26, 2009) (“condemn[ing] the recent resurgence in fighting and calls for the end of all hostilities, acts of armed confrontation and efforts to undermine the Transitional Federal Government ....").

199. See, e.g., Jonathan Saul \& Camila Reed, Shabaab-Somali pirate links growing: UN adviser, REUTERS (Oct. 20, 2011), http://www.reuters.com/article/2011/10/20/ozatp-somalia-shabaabpirates-idAFJOE79J0G620111020; see also Richard Lough, Piracy ransom cash ends up with Somali militants, REUTERS (Jul. 6, 2011), http://www.reuters.com/article/2011/07/06/somalia-piracy-idUS LDE7650U320110706; Khaled Wassef, Al Qaeda Urges Somalis To Attack Ships, CBS (Apr. 16, 2009), http://www.cbsnews.com/8301-503543_162-4949488-503543.html.

200. See Milena Sterio, Fighting Piracy in Somalia (and Elsewhere): Why More Is Needed, 33 FORDHAM INT'L L.J. 372, 388 (2010) ("The SUA Convention . . . does solidify the link between piracy and terrorism, by treating piracy as a form of maritime terrorism and by equating the jurisdictional basis 
this point, however, it does not seem that the links are robust enough to bring organized pirate groups within the relevant threshold. ${ }^{201}$ But it would be a scenario to watch closely as the circumstances may evolve.

C. If IHL were not applied, what law would apply?

If IHL is ultimately found not to apply, it would present a significant challenge to the effective use of force ashore in Somalia under the provisions of Resolution 1851. Certain parts of the Council's mandate might still be carried out, but force would be limited to that allowed under Somali domestic law and the international human rights law obligations of the states giving effect to the Council's decision. ${ }^{202}$

The Security Council specifically noted the applicability of human rights law in Resolution 1851, but did not specify the scope of its application. Broadly applicable international human rights norms are reflected in the International Covenant on Civil and Political Rights (ICCPR). ${ }^{203}$ Some international human rights instruments even contain a right to property, which could complicate the ability of states to neutralize pirates' weapons and materiel without judicial process. ${ }^{204}$ Under a human rights law framework, the targeting of any pirate-fighter would likely be disallowed except in cases of immediate self-defense.

A full analysis of various member states' individual obligations under human rights law is beyond the scope of this Article. The issue is highlighted only to note the significant challenges it presents to fully implementing the Council's decision without applying IHL. Another significant challenge, and one that has generated great debate, is the "overlap problem" of competing IHL and HRL obligations. ${ }^{205}$ These challenges are confounded by the nature of human rights legal instruments themselves. Rather than the more universal norms that characterize IHL,

for the capture and prosecution of pirates with those that already exist in other antiterrorist conventions for the capture and prosecution of terrorists.").

201. See Singh, supra note 7.

202. Somalia would be obligated to ensure that such law is consistent with international human rights obligations.

203. ICCPR, supra note 73.

204. Id. art. 9. See also European Convention for the Protection of Human Rights and Fundamental Freedoms art. 1, Nov. 4, 1950, 213 U.N.T.S. 222 ("Every natural or legal person is entitled to the peaceful enjoyment of his possessions"). The European Court of Human Rights has held that the convention applies extraterritorially, possibly complicating many nations from participating in UN enforcement actions.

205. See generally United NATIONS, International Legal Protections of Human Rights in ARMED CONFLICT, U.N. Doc. HR/PUB/11/01, U. N. Sales No. E.11.XIV.3 (2011), available at http:// www.ohchr.org/Documents/Publications/HR_in_armed_conflict.pdf; see also Sassoli \& Olson, supra note 174 
human rights obligations are implemented in states' domestic law and vary considerably from state to state and especially by region. This could potentially impact international cooperation in the fight against piracy in a significant way.

Thus, applying only international human rights law to the Security Council's decision in Resolution 1851 presents significant challenges to effectively carrying out the Council's mandate. These questions and challenges would be more satisfactorily addressed if IHL were found to apply to the Council's call for the use of force to fight organized piratefighters in Somalia.

\section{CONCLUSION}

Using targeted force on land in Somalia to cripple pirate-fighters' capacity to violently attack civilian shipping and hold innocent mariners hostage is fully supportable under international law. There are persuasive reasons that IHL should apply to the use of limited force against armed pirates in Somalia. If a NIAC is determined to exist, IHL clearly applies. But even if there is no NIAC, the situation invokes a dynamic and evolving problem in the application of IHL to emerging and unique "gray zone" conflicts. IHL is specifically cited by the U.N. Security Council, and is the lex specialis applicable to the use of force. The level of force authorized, and indeed already executed, is beyond mere police action and beyond the applicable scope of human rights law.

Piracy itself is an international crime. ${ }^{206}$ It is only with the talismanic "all necessary measures" language of Resolution 1851 that the Security Council authorized force under Chapter VII. ${ }^{207}$ Should such use of force ashore constitute sound policy, this analytical framework will hopefully be useful in showing how operations can be planned and conducted to satisfy international law. The use of limited force ashore is intended to be narrowly tailored to eliminate dangerous pirates' means of carrying out lethal attacks at sea and threatening mariners worldwide.

Some scholars have argued that using force ashore to combat piracy would be unwise. ${ }^{208}$ This may very well be the case, and I do not attempt to conflate difficult questions of policy with important questions of law. Even if attacks at sea were not approaching their lowest level in years, there still may have been sound policy reasons not to use force. Using

\footnotetext{
206. See UNCLOS, supra note 15, art. 101, 105.

207. S.C. Res. 1851, supra note 9, at 92.

208. Lesley Anne Warner, An Appraisal of U.S. Counterpiracy Options in the Horn of Africa, 63 NAVAL WAR COLL. REV. 61, 75 (2010).
} 
force on Somali territory may have the unintended side effect of increasing violence against ships and current hostages. There could also be unexpected collateral damage. Another important consideration is the international community's pursuit of other development goals in Somalia, including supporting the nascent federal government and fighting terrorist organizations, specifically Al Shabaab.

While those are some of the better arguments against using force ashore, there are also relatively bad ones. Several commentators have effectively apologized for the pirates' actions, going so far as to credit their acts to "defend their coasts and support their communities."209 The families of the hundreds who have been held hostage under inhumane conditions, or those who have been killed in piracy attacks, probably do not see it the same way. If action ashore has been held in abeyance for policy reasons, which is likely the case, it would be much better held under the former set of arguments.

It is true that piracy attacks have been receding. But there is also indirect evidence that pirates and even innocent fisherman are being killed by overeager and untrained security guards embarked on vessels transiting pirate-infested waters. $^{210}$ If the recent receding of maritime piracy off Somalia is due to private embarked security teams killing seafarers, it may be time to rethink any assumption that the use of targeted force ashore is too risky, or less humane. Furthermore, prosecution strategies, though expanding, have not proven to be an effective deterrent. ${ }^{211}$

It is time to at least acknowledge the lawfulness of decisive actionashore on Somali land territory with the full consent of the sovereign and the U.N. Security Council - to uphold the rule of law and ultimately to protect innocent mariners at sea. As I have shown, a functional approach

209. See Stillwell, supra note 144, at 136-37.

210. See Bockmann \& Katz, supra note 14.

211. Some have maintained that changes in U.S. law are needed to more effectively fight piracy. See Pines, supra note 80 , at 99 . This may be true, but only to prosecute piracy in the courtroom. It remains to be seen how effective prosecuting piracy in the courtroom will prove. It is incredibly difficult. See, e.g., Eugene Kontorovich, A Guantanamo on the Sea: The Difficulty of Prosecuting Pirates and Terrorists, 98 CAL. L. REV. 243 (2010). Furthermore, there is little evidence that prosecuting pirates at all has served as any sort of deterrent to pirate attacks. Yvonne M. Dutton, Maritime Piracy and the Impunity Gap: Insufficient National Laws or A Lack of Political Will?, 86 TUL. L. REV. 1111, 1114 (2012). Others have also suggested government security teams, which might be one reasonable approach. See James W. Harlow, Soldiers at Sea: The Legal and Policy Implications of Using Military Security Teams to Combat Piracy, 21 S. CAL. InTERDISC. L.J. 561, 565 (2012) (proposing the widespread deployment of military security teams). But there are thousands of ships out there and 2.5 million square miles of sea. That amounts to a lot of government-provided embarked security teams. 
that applies IHL would fully employ the legal tools available to address this international problem. 